2016

\title{
Payment Law: Legislative Competence in Canada
}

Benjamin Geva

Osgoode Hall Law School of York University, bgeva@osgoode.yorku.ca

Follow this and additional works at: https://digitalcommons.osgoode.yorku.ca/olsrps

Part of the Commercial Law Commons, and the Legislation Commons

\section{Recommended Citation}

Geva, Benjamin, "Payment Law: Legislative Competence in Canada" (2016). Osgoode Legal Studies Research Paper Series. 160. https:// digitalcommons.osgoode.yorku.ca/olsrps/160 


\section{OSGOODE HALL LAW SCHOOL \\ LEGAL STUDIES RESEARCH PAPER SERIES}

Research Paper No. 51

Volume 12, Issue 11, 2016

\section{Payment Law: Legislative Competence in Canada Banking and Finance Law Review, Vol. 31(1), 2015.}

\section{Benjamin Geva}

This paper can be downloaded free of charge from:

http://ssrn.com/abstract=2767604

Further information and a collection of publications from the Osgoode Hall Law School Legal Studies Research Paper Series can be found at:

http://www.ssrn.com/link/Osgoode-Hall-LEG.html

\section{Editors:}

Editor-in-Chief: Carys J. Craig (Associate Dean of Research \& Institutional Relations and Associate Professor, Osgoode Hall Law School, York University, Toronto)

Production Editor: Kiana Blake (Osgoode Hall Law School, York University, Toronto)
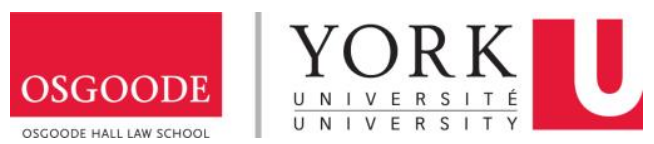
Osgoode Legal Studies Research Paper No. 51

Vol. 12/ Issue. 11/ (2016)

\title{
Payment Law: Legislative Competence in Canada
}

Banking and Finance Law Review, Vol. 31(1), 2015.

\author{
Author(s): \\ Benjamin Geva \\ Osgoode Hall Law School \\ E: BGeva@osgoode.yorku.ca
}




\section{Payment Law: Legislative Competence in Canada}

\section{Benjamin Geva*}

This article addresses the legislative competence in Canada in relation to regulatory and transactional aspects of payment law. Setting out the parameters of "payment law," the article examines the federal legislative powers in relation to bills and notes as well as banking, in broader constitutional and historical context, and argues for federal jurisdiction. A possible legislative role for the provinces is also discussed.

L'auteur se penche dans cet article sur la compétence législative au Canada relativement aux aspects réglementaire et transactionnel des lois sur les paiements. En soulignant les caractéristiques de ces lois, il étudie les pouvoirs législatifs fédéraux à l'égard des lettres de change, des billets, des activités bancaires et dans un contexte constitutionnel et historique plus large, il en vient à la conchusion qu' il s'agit d'une compétence fédérale. L'auteur évoque également un rôle législatif éventuel pour les provinces.

\section{Table of Contents}

1. Introduction

2. Legislative Power in Relation to Bills and Notes

3. "Payment Orders" and the Power to Legislate in Matters Relating to Bills and Notes

4. Deposit-Taking and Legislative Power in Relation to Banking

5. Is There Scope for Provincial Law?

6. Conclusion

\section{INTRODUCTION}

"Payment" is broadly defined to mean "any act offered and accepted in performance of a money obligation." In its simplest sense, "payment" signifies the performance of an obligation by the delivery by the payer to the payee ${ }^{2}$ of

Professor of Law, Osgoode Hall Law School, York University, Toronto (bgeva@osgoode.yorku.ca); Counsel, Torys, Toronto. For research assistance, I am grateful to Leonidas Mylonopoulos of the 2016 graduating class of Osgoode Hall Law School. Views expressed in this article - as well as all errors - are solely mine.

1 Charles Proctor, ed., Goode on Payment Obligations in Commercial and Financial Transactions, 2d ed. (London: Sweet \& Maxwell, 2009) at 11 [Goode, Payment Obligations].

2 There is no such thing as "a man paying himself." See Faulkner v. Lowe (1848), 154 E.R. 628, 2 Ex. 595 at 597 [Ex.], at 630 [E.R.], per Pollock C. (in argument). Hence, "[p]ayment, necessarily implies two distinct persons." John S. James, ed. Stroud's 
monetary objects, which at present consist of banknotes and coins ("cash"). At the same time, a payment mechanism can broadly be described as any method of payment facilitating the transmission of monetary value, particularly in the form of account debits and credits rcdeemable to monetary objects, that enables the payer to avoid the transportation of monetary objects and their physical delivery to the payee. It also makes monetary objects available for withdrawal. A payment mechanism is initiated by the payer's instructions to a third-party ("paymaster") to make the payment. ${ }^{3}$ Instructions may be written, electronic, and, under some conditions, oral.

The operation of a payment mechanism in payment of a debt is premised on the discharge of a debt owed by the payer to the payee by virtue of an authorized payment made by the paymaster. Where the paymaster is the payer's debtor, and to the extent of the sum paid, payment to the payee discharges both the payer's debt to the payee and the paymaster's debt to the payer. Alternatively, not having owed to the payer, a paymaster carrying out payment, besides discharging the payer's debt to the payee, becomes entitled to payment from the payer. Regardless, a paymaster's payment to the payee may be either in monetary objects or by means of a debt owed to the payee by someone designated by the payee to receive payment. In fact, the paymaster itself may be so designated.

In the ordinary course of business, both the paymaster and the receiver of payment for the payee are Payment Service Providers ("PSPs"). Typically, PSPs are deposit-taking institutions, such as banks, ${ }^{4}$ with which the payer and payee maintain deposit accounts. Banks exchange customers' payment instructions and pay each other resulting amounts owed in the exchange. The interbank exchange is termed a "clearing" and the ensuing payment is termed a "settlement." In a clearing, payment instructions may be processed either manually or in an automated system, and either in bulk or individually. Payment instructions may be settled either bilaterally or multilaterally, as well as either on a deferred ne settlement basis (DNS) or in real time such as in an RTGS (real-time gross settlement) system. Typically, for each currency, ${ }^{5}$ at least the large banks settle on the books of the central bank of the country of the currency. A small bank may settle on the books of a large bank acting as its correspondent. For its part, a non-bank PSP requires the services of a bank for both incoming and outgoing customers' payments.

The national payment system has been said to be "one of the principa components of a country's monetary and financial system" and therefore

Judicial Dictionary of Words and Phrases, 5th ed. vol. 4 (London: Sweet \& Maxwell, 1977) s.v. "payment" at 1337.

For an extensive discussion on payment mechanisms, see Benjamin Geva, The Payment Order of Antiquity and the Middle Ages: A Legal History (Oxford and Portland Oregon: Hart, 2011) at 15-67.

For more on deposit-taking, banks, and banking, see Part 4, below.

5 The two distinct meanings of "currency" are further set out below in this Part. "crucial to a country's economic development." Being an entire scheme consisting of institutions, arrangements, and rules facilitating monetary payments within, into, and out of a country, usually in the currency that the country has adopted, ${ }^{7}$ a national payment system has been defined as "the configuration of diverse institutional arrangements and infrastructures that facilitates the transfer of monetary value between ... parties." 8 To that end, the modern payment system has been described as consisting of "a complex set of arrangements involving such diverse institutions as currency, the banking system, clearing houses, the central bank, and government deposit insurance." 9 Monetary value is transferred in the form of cash, often referred to as "currency," here meaning banknotes and coins. ${ }^{10}$ Alternatively, monetary value is transferred as a non-cash payment, under what is frequently referred to as a "payment transaction," which "typically involve[s] a complex process of money transfers from the deposit (or credit) account of the payer at one financial institution to the account of the payee [possibly but not necessarily] at another financial institution." 11 A payment transaction is carried out by banks via clearing facilities and may be completed by means of an interbank settlement on the books of the central bank. In the process, the payee's bank replaces the payer as the payee's debtor.

In its report on core principles for systematically important payment systems ("SIPS"), the Committee on Payment and Settlement Systems ("CPSS") of the Bank for International Settlement ("BIS") identified "legal risk" as one of five types of risk that can arise in payment systems and disrupt their operation. ${ }^{12}$ To

6 Committee on Payment and Settlement Systems ("CPSS"), General Guidance for National Payment System Development (Basle: Bank for International Settlement, 2006) at $7[$ GGNPSD].

7. Currency is referred to as the "national currency" or "official currency" of the country. It is the unit of account in which prices are set and domestic payments are to be made. Coins and banknotes ("currency") denominated in that unit of account are usually "legal tender," in which a debtor may pay and which a creditor must accept in discharge of private and public debts. Typically, the central bank is the guardian of the value of that unit of account, the issuer of coins and banknotes denominated in it, and the depositary of domestic banks' reserve or settlement accounts in that unit of account. "Currency," "national currency," and "legal tender" are defined (albeit incompletely) in, e.g., Bryan A. Garner, ed., Black's Law Dictionary, 9th ed. (St. Paul, Minn.: West, 2009) at 440 and 979. For more satisfactory definitions of "legal tender" visit <http://www.merriamwebster.com/dictionary/legal\%20tender $>$ or $<$ http://en.wikipedia.org/wiki/Legal_tender\#cite_note-0 $>$

8 GGNPSD, supra note 6 at 7

9 Marvin S. Goodfriend, "Money, Credit, Banking, and Payment System Policy" in David B. Humphrey, ed., The US Payment System: Efficiency, Risk and the Role of the Federal Reserve (Boston: Kluwer Academic Publishers, 1990) 247 at 247.

10 The two distinct meanings of "currency" are further set out below in this Part.

$"$ GGNPSD, supra note 6 at 7.

12 CPSS, Core Principles for Systematically Important Payment Systems (Basle: Bank for International Settlements, 2001) at 5 . 
meet such a risk, Core Principle I requires a systematically important payment system to have "a well-founded basis under all relevant jurisdictions." 13 Nevertheless, the "legal risk" addressed by the SIPS report is narrowly Nevertheless, the "legal re banking or clearing and settlement domain, is directed only at systematically important payment systems, and focuses on the elimination of the settlement default risk, with the view to achieving speedy elimination of the settlement default risk, with the view to achieving speedy completion of the settlement process in a safe, efficient, and certain manner.
Subsequently, however, in its 2006 Report titled General Guidance for National Payment System Development ("GGNPSD"), BIS went further. It endorsed the promotion of legal certainty through the development of a transparent, comprehensive, and sound legal framework for the payment system as a guideline for national payment system development. ${ }^{14}$

Against this background, payment law is a body of law addressing the following:

1. What constitutes "money";

2. The payment instructions to pay money;

3. Who may provide payment services;

4. The PSP-to-customer domain, covering the relationship between the customer, whether payer or payee, and the customer's PSP;

5. The customer-to-customer domain, addressing the relationship between the payer and the payee;

6. The PSP-to-PSP domain, covering the relationships and transactions among PSPs in processing and settling payment instructions; and

7. Who sets the overall policy, and who provides guidance and regulation.

In Canada, under section 91 of the Constitution Act, ${ }^{15}$ exclusive legislative In Canadia, und to Parliament "to make Laws for the Peace, Order, and good Gavada, in relation to all Matters not coming within the Classes of Subjects by this Act assigned exclusively to the Legislatures of the Provinces." of Subjects by this Act assigned exclusively to the Legislatures of the Provinees." Since payment systems and methods are not addressed by the Constitution Act, it
is tempting to argue that, if only for that reason, they fall under federal jurisdiction. However, specific powers enumerated in the Constitution Act touch upon payments, and hence complexities are introduced.

Section 91 of the Constitution Act confers on the Parliament of Canada exclusive legislative power in relation to "Matters coming within [enumerated] Classes of Subjects" which include "Currency and Coinage"; "Banking, Classes of Subjects" which include "Currency Money"; "Bills of Exchange and Promissory Notes"; and "Legal Tender." 16 At the same time, section 92 of the Constitution Act assigns to each province the exclusive power to "make Laws

13 Ibid. at 3

14 Supra note 6 at 5, 38-42 (Guideline 10) and 63-67 (Annex 4)

15 Constitution Act, 1867 (U.K.), 30 \& 31 Vict., c. 3, reprinted in R.S.C. 1985, App. II, No. 5 [Constitution Act] (originally passed as the British North America Act).

16 Ibid., ss. 91(14), 91(15), 91(18), and 91(20), respectively. in relation to Matters coming within [enumerated] Classes of Subjects" which include "The Incorporation of Companies with Provincial Objects"; "Property and Civil Rights in the Province"; and "Generally all Matters of a merely local or private Nature in the Province."17

The above-mentioned four legislative powers assigned to Parliament relate to "money," with which payment is made. "Money" is defined in a leading English case to be "that which passes freely from hand to hand throughout the community in final discharge of debts . . . being accepted equally without reference to the character or credit of the person who offers it and without the intention of the person who receives it to consume it . ." 19 More broadly, money is said to be a medium of exchange, a store of value (in fact of purchasing power), ${ }^{20}$ and a unit of account. ${ }^{21}$ Typically, in its concrete form, it consists today of coins and banknotes sanctioned by the state. However, in modern times, the narrow "monetary base" of a country is taken to consist of the obligations of its central bank, both on banknotes it issues and on deposits it holds for commercial banks in their settlement (or reserve) accounts. The broader "money supply" in the hands of the public is taken to consist of such banknotes issued by the central banks (plus coins for small change issued either by the central bank or a government agency), together with demand deposits, held by the public in commercial banks ("bank money"). It is this "money supply" that reflects the purchasing power of a given society. ${ }^{22}$

"Legal tender" 23 is money that, at least in the absence of an agreement to the contrary, a debtor may offer and the creditor must accept in discharge of a

17 Ibid., ss. 92(11), 92(13), and 92(16), respectively

18 This power arguably extends to all means of payment even when they fall short of "money." See e.g. Bradley Crawford, "Reward Miles: An Important New Medium of Payment" (2013) 28 B.F.L.R. 213. See also Robert Kerr, "The Scope of Federal Power in Relation to Consumer Protection" (1980) 12:1 Ottawa L. Rev. 119 at 133.

19 Moss v. Hancock, [1899] 2 Q.B. 111 (Que. B.D.) at 116

20 William Stanley Jevons, Money and the Mechanism of Exchange (London, Henry S. King $\&$ Co., 1875) at 13 does not include this element in the definition. Indeed, money is a store of value only in the sense of being a "surplus" liquid resource available in one's hands for acquiring new commodities as may be needed and wished for.

21 Nigel Dodd, The Sociology of Money: Economics, Reason \& Contemporary Society (New York, Continuum, 1994) at xv. For Geoffrey Ingham, The Nature of Money (Cambridge, U.K.: Polity, 2004) e.g. at 198, "money" is effectively something that "[r]egardless of its form and substance" answers the promise and description provided (and measured) by the unit of account.

22 This is so since the essence of banking is lending the money on deposit, so that effectively both the depositors and the borrowers can use it. For a detailed economic perspective, see e.g. H.H. Binhammer \& Peter S. Sephton, Money, Banking, and the Canadian Financial System, 8th ed. (Scarborough: Nelson, Thomson Learning, 2001) at 197-220 (banking and the creation of money) and 387-432 (monetary controls and central banking).

23 For example, the general principle under s. 8(1) of the Canadian Currency Act, R.S.C. 1985 , c. C-52, is that "a tender of payment of money is a legal tender if it is made (a) in coins that are current under Section 7 [generally meaning "issued under the authority of 
debt. "Currency" has two meanings: ${ }^{25}$ it is both money in a tangible form (that is, nowadays, coins and paper money in the form of banknotes), and the unit of account in which coins and banknotes are denominated and monetary values are set. ${ }^{26}$

Undoubtedly then, legislative powers conferred on Parliament under section 1 of the Constitution Act in relation to "Currency and Coinage," "Banking" and the "Issue of Paper Money," and "Legal Tender" give Parliament exclusive jurisdiction in relation to "money." Similarly, payment instructions embodied in "Bills of Exchange and Promissory Notes" fall under exclusive federal jurisdictions. At the same time, according to the powers enumerated under section 92 of the Constitution Act, local non-bank PSPs and clearing houses, as well as private law matters affecting payments, appear to be assigned to exclusive provincial jurisdiction.

However, taking into account the overlap among legislative powers and, particularly, the encroaching impact of the enumerated federal powers on provincial jurisdiction, the plot thickens. Against this background, this article examines federal powers in relation to banking as well as bills and notes with the view of ascertaining their reach, on their own and in conjunction with powers relating to money, so as to establish exclusive or at least complete federal jurisdiction on payments.

The ensuing analysis proceeds as follows. Part 2 discusses legislative power in relation to bills and notes. It examines both the meaning of "bills" and "notes" and the aspects relating to them that fall under federal jurisdiction. Part 3 discusses the possible expansion of the bills-and-notes power beyond the natural meaning of these words. Part 4 addresses the "banking" legislative power as the most promising option for a broad federal power relating to payments. Part 5 sets out options for the exercise of legislative powers by the provinces. Concluding Part 6 recommends comprehensive federal regulation and legislation of all payment methods and systems.

The Royal Canadian Mint Act"]; and (b) in notes issued by the Bank of Canada pursuant to the Bank of Canada Act intended for circulation in Canada."

24 Cf. Bryan A. Garner, ed., Black's Law Dictionary, 9th ed. (St. Paul, Minn.: West, 2009) ." "legl tender" at 979 , defined as "[t]he money (bills and coins) approved in a country s... "legal tender" at the purchase of goods and other exchanges for value." For more satisfactory definitions of "legal tender" visit

$<$ http://www.merriam-webster.com/dictionary/legal\%20tender $>$ or

$<$ http:/en wikipedia.org/wiki/Legal tender\#cite note-0 >

25 "Currency" and "national currency" are defined (albeit incompletely) in, e.g., Black's Law' Dictionary, ibid. s.v. "currency" at 440, s.v. "legal tender" at 979.

26 For example, under s. 3(1) of the Canadian Currency Act, supra note 23, "The monetary unit of Canada is the dollar."

\section{LEGISLATIVE POWER IN RELATION TO BILLS AND NOTTES}

Under subsection 91(1)(18) of the Constitution Act, "Bills of exchange and promissory notes" ("bills and notes") constitute one of "the Classes of Subjects" assigned to exclusive federal jurisdiction. The concluding clause of section 91 is thus to be read as stating that "any Matter coming within ['bills and notes'] shall not be deemed to come within the Class of Matters of a local or private Nature comprised in the Enumeration of the Classes of Subjects by this Act assigned exclusively to the legislatures of the Provinces." According to Falconbridge, this "makes it plain that some of the classes of subjects enumerated in section 92 in general terms (notably 'property and civil rights in the province') must be modified or limited in their scope so as to leave room for the classes of subjects enumerated in section 91."27 It follows that provincial legislation in matters coming within "bills and notes" is constitutionally invalid, notwithstanding the fact that it could be viewed as legislation "in relation to matters coming within ... Property and Civil Rights in the Province" under section 92(13) of the Constitution Act.

Central to the ensuing analysis pertaining to this legislative power is the doctrine of progressive interpretation as a means by which courts have been able to ensure that the Constitution Act, 1867, which has been amended infrequently since its enactment, is adapted to changes in Canadian society. According to Hogg, the doctrine stipulates that the general language used to describe the various heads of power is not to be "frozen in the sense in which it would have been understood in 1867." 28 Instead, the Act must be given a progressive interpretation so that it can be adapted to new conditions and ideas. Thus, in Edwards v. Canada (Attorney General) (1929), ${ }^{29}$ the Privy Council held that "the [Constitution] Act planted in Canada a living tree capable of growth and expansion within its natural limits." Hogg believes that the metaphor is now more generally accepted. He emphasizes that progressive interpretation does not enable the courts to go beyond the normal constraints of statutory interpretation. All that progressive interpretation dictates is that the original understanding is not binding forever, and that new ideas, conditions, or inventions can fit within the constitutional language. ${ }^{30}$

The expression "matters coming within ... Bills of exchange and promissory notes," to which exclusive federal legislative power applies under subsection 91(1)(18) of the Constitution Act, is not entirely self-explanatory. In principle,

27 Arthur Wyckoff Rogers, Falconbridge on Banking and Bills of Exchange, 7th ed. (Toronto, Canada Law Book, 1969) at 24 [Falconbridge on Banking].

28 Peter W. Hogg, Constitutional Law of Canada, 5th ed, supp. (Toronto: Carswell, 2011) at $15-48$.

29 (1929), [1929] UKPC 86, 1929 CarswellNat 2, [1930] I D.L.R. 98, (sub nom. Reference re s. 24 of the Constitution Act, 1867) [1929] 3 W.W.R. 479, [1930] A.C. 124 (Jud. Com. of Privy Coun.) at para. 54.

30 Hogg, supra note 28 at $15-50$. 
three sets of questions arise. The first is the meaning of "bills and notes" to which this legislative power applies. The second is which aspects pertaining to bills and notes are "matters coming within bills and notes." The third is whether the meaning and function of bill and notes warrant the extension of the bills and notes legislative power to related instruments and facilities. The first two questions are discussed in this part, while the third question is discussed below in part 3. The remaining scope for provincial jurisdiction is linked to the second question and is discussed below in Part 5. Whether the meaning of "bills and notes" has been changed (the first question) and whether the power to legislate in relation to bills and notes is to be given a broader meaning are two ways in which the doctrine of progressive interpretation is considered.

\section{(a) What Are "Bills and Notes"?}

Exercising its power under subsection 91(1)(18) of the Constitution Act, federal Parliament passed the Bills of Exchange Act ("BEA"). Under its section $16(1)$

A bill of exchange is an unconditional order in writing, addressed by one person to another, signed by the person giving it, requiring the person to whom it is addressed to pay, on demand or at a fixed or determinable future time, a sum certain in money to or to the order of a specified person or to bearer.

A specific category of the bill is the "cheque," defined in section 165(1) as "a bill drawn on a bank, payable on demand."

Finally, under section 176(1),

A promissory note is an unconditional promise in writing made by one person to another person, signed by the maker, engaging to pay, on demand or at a fixed or determinable future time, a sum certain in money to, or to the order of, a specified person or to bearer.

Certainly, on their own, the $B E A$ definitions do not necessarily set the limits as to the types of instruments to which the federal power in relation to bills and notes may apply. In the absence of a dictionary meaning separate from that provided by statute, I discuss the meaning of these terms by reference to their history. Particularly, I examine the history of bills and notes, so as to explore whether their evolution has been an ongoing and ever-expanding process that whether their evolution has been an ongoing and ever-expanding process that $B E A$.

In the form in which we recognize them, bills of exchange transformed from those used in Medieval Continental Europe. ${ }^{32}$ During the late Middle Ages, the bill of exchange served to execute an exchange contract in order to facilitate both

31 Currently, R.S.C. 1985 , c. B-4.

32 For a detailed history, see e.g. Raymond Adrien De Roover, L'Evolution de la Lettre de Change XIVe-XVIIIe Siècles (Paris: Librairie Armand Colin, 1953). credit extension and the transmission of money from place to place. Under such a contract, an exporter of goods borrowed money in the local currency from a local exchange banker. Having agreed to repay the loan in the foreign market to which the goods were to be transported, and in the currency of that market, the exporter instructed his representative in the foreign market to repay the exchange banker's representative or correspondent in that market. Typically, it was envisaged that payment in the foreign market would be made out of the proceeds realized from the sale of the goods there. Payment was typically due at usance: namely, after a certain fixed period of time determined by mercantile custom for each pair of commercial centres. ${ }^{33}$

Subsequently, towards the end of the 17 th century, bill-of-exchange practice had been significantly transformed such that the instrument had also come to facilitate the remittance of funds between two places domestically and in situations unrelated to the performance of an exchange transaction. In England, the turning point is demonstrated by Chat v. Edgar (1662). ${ }^{34}$

Cheques and banknotes evolved in England as part of the goldsmith banking system over the second half of the 17th century. Goldsmiths received deposits and issued receipts with respect to them. ${ }^{35}$ The receipt contained the goldsmith's undertaking to pay on demand when presented with the receipt. It came to be known as a goldsmith or banker note and evolved into an early form of the promissory note. ${ }^{36}$ The latter partly superseded the deed or "specialty" as a debtor's credit payment obligation. Alternatively, rather than taking goldsmith notes, a depositor was allowed to draw upon the goldsmith various amounts up to the amount of the deposit. Such drafts, payable on demand and made out to a payee or bearer, were cheques. ${ }^{37}$

Notwithstanding Holdsworth ${ }^{38}$ and Holden ${ }^{39}$ to the contrary, the cheque did not emerge as "a special type of bill of exchange." In effect, the cheque had been originated in Ptolemaic Egypt. ${ }^{40}$ Having reappeared in Continental Europe as an improvement to a funds transfer in which both the payer and payee had to attend

33 Much of the historical discussion below is derived from chapters 8 to 10 of Geva, supra note 3 .

34 (1662), 83 E.R. 1156, 1 Keb. 636 (Eng. K.B.)

35 Richard David Richards, The Early History of Banking in England (New York: A.M. Kelley, 1965) at 40-43 (reprint of the 1929 edition)

36 James Milnes Holden, The History of Negotiable Instruments in English Law (London: University of London The Athlone Press, 1955; W.M.W. Gaunt \& Sons, 1993 (reprint)) at $70-73$.

37 For this development, see Holden, ibid. at 206-10, 212-14.

38 William Searle Holdsworth, A History of English Law, 2d ed. (London: Methuen, Sweet \& Maxwell, 1937; 1966 (reprint)) vol. 8 at 190.

39 Holden, supra note 36 at 204 (from which the ensuing quote is taken). See also at 208.

40 Raymond Bogaert, "Note sur l'Emploi du Cheque dans l'Egypte Ptolemaique" in TrapeziticaAegyptiaca, Recueil de Recherches sur la Banque en Egypte Gréco-Romaine (Florence: Edizioni Gonelli, 1994). See Geva, supra note 3 at 150-152. 
the banker together, ${ }^{41}$ the cheque was "imported" by England. During the late 17 th century, it became apparent that both bills and cheques were orders, and that they operated as payment mechanisms so that the cheque appeared to fall into the definition of the bill as if it was a subcatcgory of the bill. ${ }^{42}$ Ultimately, in into the definition of the bill as if it was a subcatcgory of the bill. distinguish it from an ordinary bill of exchange. Otherwise, however, Byles J. was of the view that a cheque "has ... all the incidents of an ordinary bill of exchange" 44 and, as such, "falls within the class of ordinary bills of exchange."

By the end of the 18th century, clear distinctions were drawn between the three types of instruments: particularly, that the bill and cheque were orders and the note was a promise. However, common elements also crystallized. Thus, it was held then that both the order (for bills and cheques) and the promise (for notes) must be "unconditional." Holden ${ }^{46}$ cites Pearson v. Garrett $(1693)^{47}$ as the notes) must be "unconening of a source for the rente $(1723)^{49}$ as a possible source for the rule under which a bill must not be stated to be payable out of a particular fund. Numerous cases requiring that " $[t]$ he payment of money mentioned in a bill or note must be certain" so as not to be subject to contingencies are cited by Bayley, ${ }^{50}$ whose book, originally published in 1789 , is viewed by Holden as "most valuable" and "scholarly" so that "[i]t may be regarded as the first modern text-book on the law relating to negotiable instruments." 51

As well, primarily in the course of the 18 th century, bills, notes, and cheques had become negotiable. "Negotiability" denotes (i) the transferability of a legal title to a sum of money by the delivery (either with or without an endorsement) of the paper containing the liability to pay it, and (ii) the potential for such

41 For a discussion and sources, see Geva, supra note 3 at 363-64.

42 Cf. Robert Samuel Theodore Chorley, "The Cheque as Mandate and Negotiable Instrument" (1939) 60 Journal of the Institute of Bankers 391 at 392, speaking on the mande on a cheque as taking the form of a bill of exchange as "a historical accident."

43 (1860), 8 C.B.N.S. 372, 141 E.R. 1210 (Eng. C.P.).

44 Ibid. at 381 (C.B.), 1213 (E.R.)

45 Ibid. at 381 (C.B.), 1214 (E.R.)

46 Supra note 36 at 107.

47 (1693), 87 E.R. 371, 4 Mod. 242 (Eng. K.B.)

48 Supra note 36 at 106.

49 (1723), 92 E.R. 386, 2 Ld. Raym. 1361 (Eng. K.B.).

so John Bayley, Short Treatise on the Law of Bills of Exchange, Cash Bills, and Promissory Notes (London: Temple Bar, 1789) at 3 (authorized facsimile: University Microfilms International, 1981). Relevant cases are cited and summarized at 3-5.

s1 Holden, supra note 36 at 143.

52 For Dutch origins, see Dave De Ruysscher, "Innovating Financial Law in Early Modern Europe: Transfers of Commercial Paper and Recourse Liability in Legislation and Iu Commune (Sixteenth to Eighteenth Centuries)" (2011) 19:5 E.R.P.L. 505. transferability to confer on the transferee title free from third-parties' adverse claims and prior parties" defences. ${ }^{53}$ In effect, "negotiability" became the common denominator bringing bills, cheques, and notes into a unified, specific branch of law. ${ }^{54}$

It is apparent that in passing the $B E A$ in $1890^{55}$ and following the U.K. definition from 1882, far from restricting the meaning of "bills of exchange and promissory notes" or even taking upon itself to define the terms from scratch, the Canadian Parliament adhered to what had been viewed then as bills of exchange and promissory notes. Furthermore, it seems evident that the meaning of "bills" and "notes," as had been crystallized by the end of the 18th century, has not evolved since then. Accordingly, in ascertaining the plain meaning of these words, it is difficult to argue that Parliament has unfettered discretion or a free hand to define and extend the list of "bills of exchange and promissory notes" or to confer on them new features that depart materially from the historical understanding of the features of such instruments. Parliament may redefine and refine specific elements and certainly provide for other reforms, but only for instruments that have been fundamentally viewed as of the 18th century or so as bills or notes.

\section{(b) What Matters Come Within "Bills and Notes"?}

Having explored the meaning of "bills and notes,"I proceed to examine the meaning of "matters coming within bills and notes" 56 which is not an entirely self-explanatory expression. The uncertainty stems from the multifaceted nature of a bill or note and the law applicable to it as such. According to Chafee, ${ }^{57}$ "a bill or note . . . is both a chattel and a chose in action." Being "a tangible scrap of paper," it is a chattel. Containing "a bundle of contracts," it is also a chose in action. As such the bill and note is governed by the general law dealing with property and obligations. 58

Ownership of a bill or note "involves not only the right to possess the thing but the right to sue" parties liable thereon, ${ }^{59}$ As such, a bill or note is "a

53 Denis Victor Cowen \& Leonard Gering, Cowen on the Law of Negotiable Instruments in South Africa, 5th ed., vol. 1 (Cape Town: Juta, 1985) at 31-36.

54 For pointing out that, in order to circulate freely, a negotiable instrument cannot be "encumbered with conditions and contingencies" and hence must contain an unconditional promise or order, see e.g. Carlos v. Fancourt (1794), 101 E.R. 272, 5 Term Rep. 482

55 Bills of Exchange Act, S.C. 1890 , c. 33.

56 This is an abbreviated form of "matters coming within ... Bills of exchange and promissory notes" under s. 91(18) of the Constitution Act. It is adopted here for convenience.

57 Z. Chafee, "Rights in Overdue Paper" (1918) 31 Harv. L. Rev. 1104 at 1109.

58 See e.g. Anthony Gordon Guest, Chalmers and Guest on Bills of Exchange, Cheques and Promissory Notes, 17th ed. (London: Sweet \& Maxwell, 2009) at ss. 5-062 to 5-066, dealing with the transmission of negotiable instruments by operation of law.

59 Chafee, supra note 57 at 1109 
documentary intangible," or more specifically, "a document of title to money," serving as "the physical embodiment of the payment obligation." "[t]he debt claim is 'merged' or 'reified' into the paper evidencing the claim." 6 Effectively it is akin to what German civilian jurisprudence calls a Wertpapier, ${ }^{62}$ defined in Article 965 of the Swiss Code of Obligations as "any document in which a right is incorporated in such a way that it cannot be claimed nor transferred to others. . . without the document." 63

Anglo-Canadian law may not have accorded bills and notes all the features of the Wertpapier. Indeed, the transfer of a bill or note to a "holder" 64 by the claim to the debt embodied in the instrument. At the same time, AngloCanadian law has failed to recognize the legal title of a non-holder transferee by delivery of a bill or note. Rather, it treats him as a mere equitable assignee. ${ }^{66} \mathrm{As}$ well, in principle, bills and notes may be assigned without the transfer of possession. ${ }^{67}$ However, Anglo-Canadian law developed a specialized distinct body of law dealing with specific proprietary and obligatory characteristics of a bill or note, such as in matters relating to the form, issue, liability, negotiation,

60 E. McKendrick, ed., Goode on Commercial Law, 4th ed. (London: Penguin Books, 2010) at 513 . See also Cowen \& Gering, supra note 53 at 53

61 G. Gilmore, "The Commercial Doctrine of Good Faith Purchase" (1954) 63 Yale L.J. 1057 at 1064

62 I agree with Cowen \& Gering, supra note 53 at 94 , that the word "Wertpapier" cannot be well translated to English, so that words such as "security" or "commercial paper" do not convey its accurate sense.

63 Swiss Code of Obligations, trans., vol. 3, rev. ed. (Zurich: Swiss-American Chamber of Commerce, 2003). On the German Wertpapier, see in general Leon Dabin, Fondements du Droit Cambiare Allenand (Liège: Faculté de Droit de Liège, 1959) at 236-84. For comprehensive discussion on the German conceptual framework, as well as whether it sheds additional light on the nature of a negotiable instrument, see Cowen \& Gering, ibid. sheds additional light on the nature of a negotiable instrument, see Cowen \& Gering, ibid. at 79-98 (where a slightly different translation, albeit to the same effect, of the Swiss sheds additional light on the nature of a negotiable instrument, ibid. at 110 , is criticized by JT. Pretorius' review of the book, (1986) 103 S.A.L.J. 151 at 154-56. On the negotiable Pretorius \& S.F. Du Toit, Malan on Bills of Exchange, Cheques and Pronissory Notes in South African Law, 5 th ed. (Durban: LexisNexis, 2009) at 4, 7 .

64 Being "the payee or endorsee of a bill or note who is in possession of it, or the bearer thereof." See $B E A$, supra note 31 , s. 2 .

${ }_{65}$ Under $B E A$, ibid., s. 59(1), "A bill is negotiated when it is transferred from one person to another in such a manner as to constitute the transferee the holder of the bill."

66 See e.g. Aldercrest Developments Ltd. v. Hamilton Co-Axial (1958) Ltd. (1973), 1973 CarswellOnt 240, 1973 CarswellOnt 240F, [1974] S.C.R. 793, 37 D.L.R. (3d) 254 (S.C.C.); affirming 1970 Carswellont 750, [1970] 3 O.R. 529, 13 D.L.R. (3d) 425 (Ont C.A.), where the bona fide party liable on a note got a discharge from the out-ofpossession transferor.

67 Guest, supra note 58, s. 5-067. and discharge. Governed by this law, a bill or note is said to be not only an obligation (or obligations) contained in a chattel but also a "negotiable instrument," namely, "a document governed by the specific legal principles applying to negotiable instruments." 68

The set of laws dealing with the application of general law is "the law of bills and notes in the wide sense." At the same time, the set of laws providing for the specific elements of the bill or note as a negotiable instrument is described as "the law of bills and notes in the strict sense." 69

Nonetheless, while over the years negotiability has become a distinctive mark of bills, cheques, and notes, ${ }^{70}$ the nature of a bill or note as a "negotiable instrument" does not convey the full scope of what falls into "strict sense" matters. Historically, the negotiability quality was a feature attributed to bills and notes as they had been evolving irrespective of this quality. The focus of the evolution had been the liability on a bill or note in "an action upon the case" on the basis of "the custom of merchants." 71 Regardless, the $B E A$ even provides for a non-negotiable bill or note. ${ }^{72}$ Hence, "negotiability" is a too narrow component of the "strict sense" law, the evolution of which had been well underway irrespective of whether, and before, these instruments acquired negotiability. As a subject of a specific set of laws, a bill or note is thus a "negotiable instrument" in the sense of being governed by the law addressing matters pertaining specifically to bills and notes which include, but nonetheless are not restricted to, negotiability.

Certainly strict-sense aspects are "matters coming within bills and notes" allocated to the federal government under section 91(18) of the Constitution Act. There is, however, a controversy as to whether federal "bills and notes" jurisdiction is limited solely to these aspects. Based on a historical approach, LeClair submits that the answer is in the affirmative, so that the exclusive jurisdiction given in 1867 to the federal Parliament is confined to matters coming within the law of bills and notes in the strict sense. ${ }^{73}$ On the other hand, Crawford, ${ }^{74}$ in the footsteps of Falconbridge, ${ }^{75}$ appears to consider Parliament's

68 Aharon Barak, "The Nature of the Negotiable Instrument" (1983) 18 Isr. L.R. 49 at 75.

69 See in general Aharon Barak "The Requirement of Consideration for Bills or Notes in Israel" (1967) 2 Isr. L.R. 499 at 500-505. See also Bradley Crawford, The Law of Banking and Payment in Canada, vol. 3, looseleaf (Toronto: Canada Law Book, 2008) at ss. $20: 30.20(2)$ and $21: 40.80(3)$.

70 See Part 2(a), above.

71 See e.g. Chat and Edgar Case (1663), supra note 34

72 See $B E A$, supra note 31 , s. 20(1), governing "a bill [containing] words prohibiting transfer, or indicating an intention that it should not be transferable."

73 Jean LeClair "La Constitution par l"histoire: portée et étendue de la compétence fédéral en matière de lettres de change et de billets à ordre" (1992), 33 Les Cahiers de droit 535.

74 Crawford, Banking and Payment, vol. 3, supra note 69, s. 23:40.80(2).

75 Rogers, Falconbridge on Banking, supra note 27 at 586. 
jurisdiction to be broader so as to include "legislation ancillary or incidental to bills and notes legislation" and dealing with "wide sense" matters.

The problem I see with Crawford's view is that the very' existence of federal ancillary and incidental jurisdiction in Canada is not settled. In the absence of such an express power in the Constitution Act, as for example in the United States ${ }^{76}$ and Australia, ${ }^{77}$ the existence of an ancillary federal power in Canada is controversial. ${ }^{78}$ On one occasion, it was said that "the ancillary power doctrine" exists and yet is "limited to what is truly necessary for the effective exercise of Parliament legislative authority." 79 On another occasion, the existence of the doctrine was rejected; rather it was said that federal legislation is to be upheld as long as it has a "rational, functional connection" with the relevant federal head of power. ${ }^{80}$ In an attempt to reconcile between these two views, it was held that the former view applies only in the case of a serious encroachment by federal legislation on a provincial power. ${ }^{81}$ Disapproving of this compromise, Hogg describes it as making "the answer to a simple question too complicated, too discretionary, and therefore to unpredictable." 82

In limiting federal jurisdiction to strict-sense matters on the basis of his understanding of history, LeClair's view appears to smack of "originalism." At the same time, his approach undermines uniformity throughout the country which historically might well have been the very reason for assigning jurisdiction in relation to bills and notes to Parliament. If so, it is up to Parliament to determine where lack of uniformity in the area may be tolerated so as to withhold legislation. I am thus not opposed to the "rational, functional connection" test, ${ }^{83}$ except that, as explained in Part 4 below, in the footsteps of Hogg, I am not sure of its utility. Rather, in my view, to the extent that the ancillary power doctrine does not exist in Canada without restrictions, the expression "matters coming within bills and notes" ought to be taken to be broad enough to cover the entire law of bills and notes, in its wide as well as its strict sense. It is unlikely, indeed, that the Constitution Act purported to deprive the Parliament of Canada of the

76 U.S. Const. art I, \& 8, cl. 18.

77 Commonwealth of Australia Constitution Act, s. 51(39).

78 Hogg, supra note 28, s. 15.9(c).

79) R. v. Foundation Co. of Canada Ltd. (1979), 1979 CarswellNat 629, 1979 CarswellNat 189, (sub nom. R. c. Thomas Fuller Construction Co. (1958) Ltd.) [1980] 1 S.C.R. 695, 12 C.P.C. 248,106 D.L.R. (3d) 193, 30 N.R. 249, [1979] S.C.J. No. 124 (S.C.C.) at 713 [S.C.R.] [emphasis in the original].

80 Papp v. Papp (1969), 1969 CarswellOnt 963, [1970] 1 O.R. 331, 8 D.L.R. (3d) 389 (Ont. C.A.) at 335-336 [O.R.].

81 City National Leasing Ltd. v. General Motors of Canada Ltd., 1989 CarswellOnt 956 1989 CarswellOnt 125, EYB 1989-67447, [1989] 1 S.C.R. 641, 68 O.R. (2d) 512 (note), 43 B.L.R. 225, 24 C.P.R. (3d) 417, 58 D.L.R. (4th) 255, 93 N.R. 326, 32 O.A.C. 332, [1989] S.C.J. No. 28 (S.C.C.) at para. 69

82 Hogg, supra note 28, s. 15.9(c).

83 Supra note 81 power to legislate in relation to the general proprietary and obligatory elements of the instrument. ${ }^{84}$ Furthermore, if any legislation that addresses bills and notes meets the "rational, functional connection" test, I do not see any substantive difference between the adoption of this test and saying that federal legislative power covers wide-sense matters. ${ }^{85}$ In fact, as it stands now, the $B E A$ contains a few "wide sense" provisions. Examples are section 50 in relation to a signature by procuration ${ }^{86}$ and section 162 dealing with the exchange rate calculation for a bill payable in Canada in foreign currency.

Accordingly, the distinction between strict- and wide-sense matters becomes irrelevant in ascertaining the reach of the federal jurisdiction in matters relating to bills and notes. At the same time, as will be discussed in Part 5 below, the distinction becomes important in relation to the provincial legislative power to affect such matters.

\section{3. "PAYMENT ORDERS" AND THE POWER TO LEGISLATE IN MATTERS RELATING TO BILLS AND NO'TES}

At the moment, a paperless electronic authorization record does not qualify as an instrument falling under the $B E A$. The latter facilitates the electronic presentment of cheques and yet requires an original paper cheque to exist. ${ }^{87}$ The Personal Information Protection and Electronic Documents Act ("PIPEDA") 88 is a federal piece of legislation providing in sections $31-51$ for electronic equivalency for paper documents. The express purpose of this part of the Act is to "provide for the use of electronic alternatives where federal laws contemplate the use of paper to record or communicate information or transactions." 89 However, in terms of requirements under federal law for a document to be in writing, an electronic document will suffice only if the federal law is listed in Schedule 2 or 3 of the Act. ${ }^{90}$ These Schedules include specific

84 Cf. the approach in Quebec (Attorney General) v. Bélanger (Trustee of), 1926 CarswellQue 3, [1926] S.C.R. 218, (sub nom. Bélanger v. Royal Bank) 7 C.B.R. 285 , [1926] 2 D.L.R. 929 (S.C.C) at 934 [D.L.R.]; affirmed 1928 CarswellNat 47, (sub nom. Quebec (Attorney General) v. Larue) 8 C.B.R. 579, [1928] 1 D.L.R. 945, [1928] 1 W.W.R. 534, [1928] A.C. 187 (Jud. Com. of Privy Coun.), dealing with the scope of the bankruptcy power of the Parliament of Canada (under what is now Constitution Act $\mathrm{s}$. 91(21)).

85 In fact, arguably, in passing (under the bills and notes legislative power) s. 16 to the Depository Bills and Notes Act, S.C. 1998, c. 13, under which "A party is liable to pay [on a depository bill or note] whether or not the depository bill or note constitutes a binding contractual obligation," Parliament provided for a wide-sense matter.

86 Rogers, Falconbridge on Banking, supra note 27 at 586.

$87 B E A$, supra note 31 , ss. 163.1-163.6, dealing with official image and electronic presentment.

88 S.C. 2000, c. 5

89 Ibid. s. 32.

90 Ibid.s. 41 
sections of the Federal Real Property and Federal Immovable Act, Canada Labour Code, and Federal Real Property Regulations. ${ }^{91}$ This significantly limits the scope of PIPEDA in this regard. However, the responsible authority in respect of a provision of a federal law has the power to order or amend Schedule 2 or 3 by adding or removing a reference to that federal law. ${ }^{92}$ While the $B E A$ is not listed in the Schedules, I do not see any preclusion from including it.

For paper payment instructions, jurisdiction issues máy not always be easily determined. For example, travellers' cheques or postal orders may not be, strictly speaking, cheques. Nevertheless, to the extent that they are treated as cheques, ${ }^{93}$ it may be argued that they fall under the federal bills and notes legislative power. Furthermore, Goodwin v. Robarts $(1875)^{94}$ stands for the proposition that the "law merchant," consisting of "the usages of merchants and traders . . ratified by the decisions of Courts of law" is an ongoing source for conferring negotiability on new types of instruments other than those provided for by the $B E A$. Accordingly, certain financial instruments not complying with $B E A$ requirements may nonetheless be treated in financial markets as "negotiable." 95 However, as set out immediately below, it remains to be seen whether courts will read the federal bills or notes power to cover negotiable instruments in general, and not only bills (including cheques) and notes.

On the one hand, plain reading of section 91(18) of the Constitution Act does not support such a broad legislative power. Federal jurisdiction under this section is not stated to relate to negotiable instruments; rather, it is stated to relate to bills and notes - and was exercised in relation to them even where they are not negotiable. ${ }^{96}$ Prima facie, then, as a matter of "Property and civil rights in the province" under section 92(13) of the Constitution Act, a province is not precluded from conferring negotiability on new types of instruments. Nor is a province precluded from legislating in relation to negotiable instruments other than bills and notes. In fact, the power of a province to legislate with regard to negotiable securities ${ }^{97}$ and documents of title to goods ${ }^{98}$ has not been questioned,

91 Ibid. Sch. 2, Sch. 3

92 Ibid. s. 49.

93 See e.g. Eliahu Peter Ellinger, "Travellers' Cheques and the Law" (1969) 19 U.T.L.J. 132.

94 (1875), L.R. 10 Ex. 337 at 346; affirmed (1876), 1 App. Cas. 476 (U.K. H.L.).

95 See e.g. Eliahu Peter Ellinger, "Legal Problems of Modern Commercial Paper" (1990-91) 6 B.F.L.R. 65

96 Features of negotiability are denied to instruments under BEA, supra note 31 , ss. 20(1) (words prohibiting transfer), 68 (restrictive endorsement), and 174 ("Not negotiable" cross).

${ }^{97}$ Cf. Ontario Securities Transfer Act, S.O. 2006, c. 8, s. 70, under which "A protected purchaser, in addition to acquiring the rights of a purchaser, also acquires the purchaser's interest in the security free of any adverse claim."

98 For a provincial statute governing negotiable warehouse receipts, see e.g. Warehouse Receipts Act, R.S.O. 1990, c. W-3. and it is not all that obvious how the case will be different for negotiable debt instruments that are neither bills nor notes. ${ }^{99}$

On the other hand, in Miller v. Race (1758), even before banknotes issued by the Bank of England became legal tender, ${ }^{100}$ Lord Mansfield rationalized their negotiability on the need to "give . . them the credit and currency of money" as if they were "current coin." 101 More than a hundred years later, negotiable instruments were said to "form part of the currency of the country." 102 Negotiability is thus a concept overarching and linking currency, paper money, and legal tender, matters that fall under exclusive federal legislative competence. ${ }^{103}$ This appears to support the existence of an exclusive federal power over the negotiability of either all circulating debt instruments or those used as means of payment. Under this view, both the attribution of negotiability and the regulation of its aspects in relation to such debt instruments are under exclusive federal jurisdiction. ${ }^{104}$ The conferment of negotiability by the "law merchant" on them is then a "strict sense" federal law matter. Negotiability conferred on such debt instruments, whether by Parliament or by a "law merchant" rule, may be regulated by the federal government and by the law merchant; either way, it is free from intervention by provincial law. Whether under this reasoning federal jurisdiction extends to other aspects of such debt instruments, or even further, to non-circulating non-negotiable payment instruments, or even more generally, to all methods of payments not premised on negotiability, will be further discussed immediately below.

Certainly, not all payment orders are embodied in cheques or other types of bills of exchange. Functional differences among various payment methods have not been overlooked by courts in diverse contexts. For example, in Tenax Steamship Co. v. Brimnes (The) (Owners) (1974), ${ }^{105}$ addressing the difference

99 In fact, s. 28(4) of the Personal Property Security Act, R.S.O. 1990, c. P-10 [OPPSA], insofar as it applies to "instruments" that are not bills and notes is such a provision. At the same time, insofar as the section purports to apply also to bills and notes and is inconsistent with $B E A$, s. 55 (1) (holding in due course requirements) OPPSA, s. 28(4) is superseded by federal law under the federal paramountcy doctrine discussed in Part 4 below. In essence, OPPSA, s. 1 defines "instrument" to be a writing that evidences a right below. In essence, $O P P S A, \mathrm{~s}$. I defines "instrument" to be a writing that evidences a right
to the payment of money and is of a type that in the ordinary course of business is transferred by delivery with any necessary endorsement or assignment. It includes but is not limited to a bill or note.

${ }^{100}$ Under s. 6 of the Bank of England Act, 1833 (U.K.), 3 \& 4 Will. IV, c. 98.

101 (1758), 97 E.R. 398, 1 Burr. 452 (Eng. K.B.) at 457[Burr.], at 401 [E.R.] [emphasis added].

102 Foster v. MacKinnon (1869), 20 L.T. 887 (Eng. C.P.) at 889.

103 Constitution Act, supra note 15, ss. 91(1), 91(14), 91(16), and 91(20), respectively.

104 This view is advanced by Jacob S. Ziegel \& David L. Denomme, The Ontario Personal Property Security Act: Commentary and Analysis, 2d ed. (Toronto: Butterworths Canada, 2000) at 20.

${ }^{105}$ [1974] 3 All E.R. 88 (Eng. C.A.) at 111-112; affirmed (1972), [1973] 1 All E.R. 769 (Que. B.D.). 
between payment by cheque and payment by credit (or telex) transfer, Megaw L.J. opined that:

there is no useful analogy between, on the one hand, a payment made by delivery ... of a cheque ... and, on the other hand, telex instructions to pay ... The receipt of a cheque is not the receipt of mere instructions. It is the receipt of an instrument - a chose in action which has an inherent value, because the holder of it obtains, by virtue of his holding of the document, a legal right to a sum on money, which right he can enforce, if necessary by action. The receipt of a telex containing instructions to transfer funds from one account into another account confers on the holder of the telex no such right. It is instructions to pay, not a payment ...

Not being "cheques" (or other types of bills), telex instructions do not appear to be covered by the "bills and notes" power under section 91(18) of the Constitution Act.

Indeed, payment transactions are either credit or debit transfers. Where the payer's instructions are communicated directly to the payer's bank, there is a credit transfer. Where the payer's instructions are communicated to the payer's bank indirectly, namely via the payee and the payee's bank, there is a debit transfer. To that end, in a debit transfer, it is common not to focus on the payer's instructions, but rather, on the payee's instructions initiated on the basis of the payer's authorization.

In a credit transfer, the payer's instructions communicated to the payer's bank "push" funds to the payee. In a debit transfer, the payee's communication to the payee's bank "pulls" or "draws" funds from the payer's account. Thus, as a matter of banking operation, a credit transfer commences with a debit to the payer's account, and is completed with a credit posted to the payee's account Conversely, a debit transfer may commence with a credit posted (albeit provisionally) to the payee's account and is completed with a debit to the payer's account. It is thus the payer's instructions to the payer's bank that initiate the banking process in a credit transfer. In contrast, it is the payee's instruction to the payee's bank that initiate the banking operation in a debit transfer. Cheques are processed as debit transfers. Telex instructions are processed as credit transfers. For certain then, telex transfers are not "cheques."

Similarly, instructions commencing preauthorized, or in fact all debit transfers initiated other than by the deposit of a cheque, are also, strictly speaking, not "cheques." This is so notwithstanding the application to such instructions of the same banking process and even of some rules relating to the enforcement of the payer's engagement on them. ${ }^{106}$ Unlike the receipt of the

106 See e.g. New York Life Insturance Co. c. Langelier-Côté (1991), 1991 CarswellQue 274, 44 Q.A.C. 14,[1992] R.R.A. 135 (C.A. Que.) (conditional payment) and Esso Petroleum Co. Ltd. v. Milton, [1997] EWCA Civ. 927, [1997] C.L.C. 634 (Eng. C.A.) (payer's defences to an action upon dishonour). cheque, those instructions do not have "an inherent value" on which the instruction-giver may be sued.

This, however, may not conclude the matter. Indeed, on more technical grounds, an instruction initiating a debit or credit transfer is not a cheque, if only because, or at least as long as, it does not direct payment to be made on demand. ${ }^{107}$ At the same time, as long as it is unconditional, is made in writing, is signed, states a sum as well as a payment date, and directs payment to a specified person, such instruction may satisfy the definition of a bill. ${ }^{108}$ So even as such an instruction is not handled as a bill or cheque governed by the $B E A$, it is not inevitable to see the legislative power under section 91(18) of the Constitution Act as not covering it.

The case of the credit card payment is an even closer call. In a nutshell, parties to a typical inter-institution credit card transaction are a cardholder, a merchant, an issuing institution, and an acquiring institution. Parties to underlying bilateral contracts are the cardholder-issuer, the cardholder-merchant, and the merchant--acquirer. The issuing and acquiring institutions are members in a card association (such as Visa or MasterCard) and are contractually bound to each other by the association rules. ${ }^{109}$ In a typical scenario, the cardholder hands the card to the merchant and authorizes payment. The merchant seeks the issuer's authorization. The acquirer credits the merchant's account and collects from the issuer. Collection is through the clearing system of the card association, while settlement of netted amounts is through usual interbank channels. The issuer sends to the cardholder a periodic statement that the cardholder pays according to their agreement.

Relying on the decision of Millett $J$. at first instance and of the Court of Appeal in Charge Card Services Ltd., Re (1986), ${ }^{10}$ Woolf L.J. held in Customs and Excise Commissioners v. Diners Club Ltd. (1989) ${ }^{111}$ that:

where a card is produced by a cardholder and accepted by a retailer and the cardholder signs the sales voucher the cardholder is unconditionally

107 Being under $B E A$, supra note 31 , s. 165(1) "a bill drawn on a bank, payable on demand."

${ }^{108}$ Being under $B E A$, supra note 31 , s. 16(1) "an unconditional order in writing, addressed by one person to another, signed by the person giving it, requiring the person to whom it is addressed to pay, on demand or at a fixed or determinable future time, a sum certain in money to or to the order of a specified person or to bearer."

109 "The contractual hierarchy" in the typical credit card situation is set out in Aldo Group Inc. v. Moneris Solutions Corp., 2012 ONSC 2581, 2012 CarswellOnt 11002, [2012] O.J. No. 1931 (Ont. S.C.J. [Commercial List]) at paras. 10-25; affirmed 2013 ONCA 725, 2013 CarswellOnt 16221, 118 O.R. (3d) 81, 22 B.L.R. (5th) 44, 51 C.P.C. (7th) 221, 370 D.L.R. (4th) 491, 313 O.A.C. 122 (Ont. C.A.); leave to appeal refused 2014 CarswellOnt 5661, 2014 Carswellont 5662 (S.C.C.) and is further discussed throughout the judgment.

110 (1986), [1986] 3 All E.R. 289, [1987] Ch. 150 (Eng. Exch.); affirmed [1988] 3 All E.R. 702, [1988] 3 W.L.R. 764 (Eng. C.A.)

111 [1989] 2 All E.R. 385 (Eng. C.A.) at 393. 
discharged from liability to pay to the retailer the amount of the cost of the goods or services.

Accordingly, in the eyes of Woolf L.J., in connection with the typical credit card scenario, it seemed "unlikely that the customer is ever indebted to the retailer." The credit card itself is certainly neither a bill nor a cheque. Rather, it is a plate or device used by the cardholder to initiate payment.

At issue, however, is not the card but rather the sales slip, sales voucher, or sales draft - all of which are interchangeable - signed by the cardholder. In Canada, manually signed paper vouchers in a card transaction have become increasingly rare; however, it is useful to examine case law that addressed them to get a sense of the judicial treatment given to them in the broader context of an analysis as to the possible reach of section 91(18) of the Constitution Act.

Thus, in North Shore Credit Union v. Cumis General Insurance Co. (1986), ${ }^{112}$ MacKenzie J.A. acknowledged that in a credit card transaction "the credit risk of non-payment by the cardholder rests with the issuer and not with the merchant's financial institution or acquirer." He nevertheless considered "[t]he foundation of the credit card system" to be "that a credit card slip will be honoured for payment throughout the sequence from cardholder to merchant and presentation is a direction to pay."113 He concluded that the sales slip constituted a "request by the drawer upon the drawee to pay money," which was a "draft," 114 the latter being an $\operatorname{order}^{115}$ that is a bill or cheque as long as it fulfills the other requirements under the $B E A$.

However, leading Canadian scholars do not support the reasoning leading to the conciusion that sales slips are drafts. According to Ogilvie, ${ }^{116}$

The cheque analogy fails in a number of ways. Unless certified or the parties otherwise agree, a cheque operates as a conditional payment and is revocable insofar as the drawer may countermand it at any time prior to actual payment. This cannot be said of a credit card transaction because the cardissuer has made a separate contractually binding promise to the merchant that the merchant will be paid, regardless of whether the cardholder pays the cardissuer. A valid

112 (2003), 2003 BCCA 692, 2003 CarswellBC 3178, 22 B.C.L.R. (4th) 219, 8 C.C.L.I. (4th) 38, [2004] 3 W.W.R. 651, 192 B.C.A.C. 199, [2004] I.L.R. I-4269, 315 W.A.C. 199, [2003] B.C.J. No. 2923 (B.C. C.A.).

113 Ibid. at para. 18.

114 Ibid, at para. 19.

115 In ibid at para 15, Mackenzie J A cited the accepted definition of "draft," taken from Hunter v. Bowyer (1850), 15 L.T.O.S. 281 (Eng. Ex. Ch.) by Pollock CB, according to which, "[T]he word "draft", no doubt, includes a bill of exchange as well as a cheque. It is a nomen generale, which embraces every request by the drawer upon the drawee to pay money."

16 Margaret H. Ogilvie, Canadian Banking Law, 2d ed. (Scarborough, Ont.: Carswell, 1998) at 706. She restates her position in Margaret H. Ogilvie, Bank and Customer Law in Canada, 2 d ed. (Toronto: Irvin Law: 2013) at 404-05. countermand of a cheque restricts the cause of action on the sale to the buyer and the seller. Failure of the cardissuer to pay results in an action for breach of the cardissuer-merchant contract and between those parties alone. Finally, the merchant has no alternative, but that chosen by the cardholder, in the bank which pay the merchant.

Crawford" "originally found [the reasoning in North Shore Credit Unionv. Cumis] to be a very satisfying theory to explain the legal foundations of credit cards" as "[i]t accords with both the modern practice and the known history of credit cards." However, in his final analysis, he points out that there are two problems with it as an explanation of the legal foundation of the modern credit card system:

It is not a reason for imposing any liability upon the drawee (i.e., the credit card issuer) to pay money. Just as a draft in the form of a bill of exchange is not binding upon the drawee until he accepts or pays it, so the credit card schemes were designed to enable the issuer to pay cardholders' sales drafts, but not to compel it to do so in every case. And that freedom from unconditional liability has been preserved to this day by the careful wording of the issuers' written agreements with cardholder and merchants... Also, if the old common law of negotiable drafts were to be fully exploited as the legal foundation for credit cards, it would impose a secondary liability on the drawer to pay the merchant if the drawee did not. .

A second difficulty that I have with the theory of Mackenzie J.A. is that it is no longer supported by the facts. When credit cards first became common and popular forms of payment, the unvarying practice was for the merchant to obtain the signature of the customer on a specially prepared multi-leaved form of sales draft, with appropriate text direct the card issuer to pay. The recital of the facts by Mackenzie J.A. indicate that the original practice was already changing by the time the sales draft in the North Shore case were signed: the text on the sales drafts is quoted by the learned justice of appeal as "authorizing" the issuer to pay merchant, not directing it to do so. Moreover, those original flimsy sales draft forms have now been universally replaced in favour of several new patterns of dealing. .

As well, in Marcotte c. Fédération des caisses Desjardins du Québec (2012), ${ }^{118}$ the Quebec Court of Appeal added an argument of its own, observing

117 Bradley Crawford, The Law of Banking and Payment in Canada, vol. 2, looseleaf (Toronto: Canada Law Book, 2008) at s. 13:10.10(2)(d) [emphasis in the original].

118 Marcotte c. Fédération des caisses Desjardins du Québec, 2012 QCCA 1395, 2012 CarswellQue 7781, 2012 CarswellQue 13752, EYB 2012-209730, [2012] R.J.Q. 1526 (C.A. Que.) at para. 68; reversed in part 2014 CSC 57, 2014 SCC 57, 2014 CarswellQue 9003, 2014 CarswellQue 9004, (sub nom. Marcotte v. Fédération des caisses Desjardins du Québec) [2014] 2 S.C.R. 805, 25 B.L.R. (5th) 277, 374 D.L.R. (4th) 643, 462 N.R. 296 (S.C.C.) at para. 18 . 
that the slip signed by the cardholder at the time of payment (or its electronic equivalent for cards with PINs) is much more akin to an acknowledgement of debt [or a reimbursement undertaking to reimburse the issuing institution according to the agreement that binds them] than to a bill of exchange that requires a drawer, drawee and payment order benefiting the merchant .

With respect, to one degree or another, these positions can be challenged, or at least qualified. Thus, and at least as long as this is not negated by a statute in relation to an instrument governed or created by it, ${ }^{119}$ whether an instrument is a "bill," "note," or "cheque" is determined exclusively by its form. Conditions contained in side agreements do not detract from the negotiability of an instrument that does not state to incorporate them. For example, it does not matter that under the drawer-drawee contract a cheque is typically drawn on a positive balance in a bank account and that, similarly, under the card-issuer and cardholder agreement, a credit card payment is typically to be charged to a credit line within agreed upon credit limits. As long as the instrument complies with the definition of a bill or cheque it is indeed a bill or cheque. Similarly, the nature of payment made by an instrument, whether conditional or absolute, is not part of the inquiry as to whether it is a bill or cheque. In general, whether payment is absolute or conditional depends in the first place on the intention of the parties, and in theory, even a "regular" payment by cheque (unsupported by card) may be held in a given case to be intended as "absolute" without undermining the qualification of the instrument as a cheque. Where the payment is supported by card, an intention for absolute payment may be presumed to exist, without denying the nature of the sales slip as a cheque. It is the form alone that determines whether an instrument is a "cheque" or a "bill." Furthermore, although payment by cheque is presumed to be conditional, ${ }^{120}$ payment by certified cheque or bank draft may be absolute. ${ }^{121}$ They are all, nevertheless, "cheques." 122

While a personal cheque can be countermanded under section 167 of the $B E A$, this is certainly not the case for a certified cheque. ${ }^{123} \mathrm{~A}$ card issuer's "separate contractually binding promise to the merchant" 124 has so far not been

119 As was the issue in Bank of Montreal v. Bay Bus Terminal (North Bay) Ltd. (1977), 1977 CarwellOnt 490F 1977 CarswellOnt 490, (sub nom. Bank of Canada v. Bank of Carswellont $490 \mathrm{n}$ Montreal) [1978] 1S.C.R. 1148, 76 D.L.R.(3d) 385,16 N.R. 33 (S.C.C.). The application of this principle to a provincial statute, Gee, Re, 1928 CarswellOnt 244, [1928] 3 D.L.R. 54,62 O.L.R. 184 (Ont. C.A.), is less convincing but is irrelevant for our purposes here.

${ }^{120}$ The classic authority is Charge Card Services Ltd., Re, [1986] 3 All E.R. 289, [1986] 3 W.L.R. 697 (Eng. Exch.); affirmed [1988] 3 All E.R. 702 (Eng. C.A.).

${ }_{121}$ For a certified cheque, see Boydv. Nasmith, 1888 CarswellOnt 23, 17 O.R. 40, [1888] O.J. No.73 (Ont C.P) (as may have been qualified by Gaden v. Newfoundland Savings Bank, 1899 CarswellNfld 1, [1899] A.C. 281, C.R. [12] A.C. 128 (Jud. Com. of Privy Coun.)).

${ }^{122}$ See in general Benjamin Geva, "Irrevocability of Bank Drafts, Certified Cheques and Money Orders" (1986) 65:1 Can. Bar. Rev. 107.

123 Ibid. at 124 . conceptualized. ${ }^{125}$ Regardless, it is not fundamentally different from that of the certifying bank or that of a drawer of a bank draft. In fact, in facilitating communication between the merchant and the issuer (albeit through the acquirer and/or a central switch) so as to enable online authorization, the credit card system is an enhancement of the cheque guarantee card. ${ }^{126}$ The latter system, under which the merchant had to rely exclusively on the card itself and the identification of the holder presenting it, never took root in Canada. This system did not facilitate the online credit card authorization that ensures at least (i) that the card itself was neither reported lost or stolen nor had been cancelled, and (ii) that the cardholder had not exceeded his or her line of credit. Not surprisingly then, the cheque guarantee card was much more amenable to fraud.

Indeed, as Crawford argues, if the sales slip is a bill or cheque, upon the default of the card issuer, recourse ought to be available against the cardholderdrawer under section 129 (a) of the $B E A$. This is contrary to the view that the credit card payment is absolute so as to release the cardholder. However, a drawer may disclaim liability by inserting an express stipulation to that effect under section 33(a) of the $B E A$. As indicated, release of the drawer from liability may be implied in the case of a certified cheque. Hence, dispensation with recourse is not inconsistent with viewing the sales slip as a bill or cheque.

This responds to Ogilvie and to the first problem addressed by Crawford. The response to his second objection as well as to the quoted language of the Quebec Court of Appeal in Fédération v. Marcotte is more subtle. As illustrated above, whether a sales slip is a "bill" or "cheque" depends on the specific language contained in the particular sales slip. Additionally, in the case of a cheque, conditions usually exist between the drawer (payer) and the drawee. What matters is that they do not appear on the cheque itself. A standard form cheque printed by the bank does not contain any condition, such as, for example, availability of adequate balance (or an overdraft privilege). The order on a standard form cheque is not even stated to pay out of the account, as the order may then be taken to be conditional on the existence of the account or balance in it; only a reference to the account is permitted. ${ }^{127}$ At the same time, in a credit card payment, even if the merchant's entitlement may be qualified, this is not different from the general rule for an instrument on which the bank is liable. ${ }^{128}$ It is not the entitlement that is unconditional, but rather the language of the promise or order forming the basis for it.

124 Ogilvie, Canadian Banking Law, supra note 116 at 706.

${ }^{125}$ This is so in the four-party credit card transactions where the issuer is not the acquirer and as such has no contractual privity with the merchant.

126 On this point, as part of the evolution of consumer or retail payment systems, see Benjamin Geva, "Consumer Liability in Unauthorized Electronic Funds Transfers" (2003) 38 Can. Bus. L.J. 207 at 212-223.

127 BEA, supra note 31, s. 16(3)(a).

${ }^{128}$ See e.g. Benjamin Geva, "The Autonomy of the Banker's Obligation on Bank Drafts and Certified Cheques" (1994) 73:1 Can. Bar. Rev. 21-56 and addendum at 280-82. 
Admittedly, however, the distinction between "order" and "authorization" appears to be more problematic. Thus, according to Guest, ${ }^{129}$

A bill is an order. It must require, and not merely request the drawee to pay. It must, therefore, in its terms be imperative and not precative. An authority to pay, for example "we hereby authorise you to pay to our account to the order of G" is not an order to pay ...

In his treatise, Crawford is even more categorical: ${ }^{130}$ ". . . a command, however politely framed, is required. A mere authorization to pay is not sufficient ..."

In support for his view, Guest cites Hamilton v. Spottiswoode (1849). ${ }^{131}$ Crawford mentions this case and yet for the insufficiency of the "mere authorization" he cites Russell v. Powell (1845). ${ }^{132}$ However, careful reading of both cases indicates that they are not all that straightforward. In Russell $v$. Powell (1845), the language was "we do hereby authorize and require you to pay." True, this was not a "mere authorization," and yet nothing in the judgment turned on it. Rather, even if authorized and required, in the facts of the case, payment was supposed to be out of a particular fund, which disqualified the instrument from being a bill. In Hamilton v. Spottiswoode (1849), Pollock CB stated that the document did not "import an absolute intention that the money should at all events be paid, but merely authorise the defendant to pay it" and hence was not a bill of exchange. However, so far as the reported case reveals, the dispute evolved around the dependence of the authorization on the existence of a fund, on the basis of which it was argued that the document expressed "a mere authority . . to pay ... upon a contingency which might never happen." Nothing turned on the existence of language merely authorizing payment. Furthermore, both cases dealt with alleged violation of stamping requirements; had the documents been found to be bills of exchange, the absence of stamping could have resulted in the release of a party liable on technicalities. This of course could explain the inclination to declare the documents as not being bills of exchange.

In connection with a cardholder's authorization, as long as the cardholder complies with the terms of the cardholder's agreement, the issuer, between itself and the cardholder, is bound to pay. Whether a payee or merchant is entitled to recover from the drawee or issuer does not depend at all on the drawer-drawee or cardholder-issuer relationship. Hence, in a commercial situation, a court may treat the "authorization" language as amounting to an order. At the same time, as indicated, the statutory test for the application of the $B E A$ is extremely and exclusively formal. Hence I cannot predict with certainty how a court will treat the authorization language in a credit card sales slip.

\footnotetext{
${ }^{129}$ Guest, supra note 58 , s. 2-008

130 Crawford, Banking and Payment, vol. 3, supra note 69, s. 22:20.20.

131 (1849), 154 E.R. 1182, 4 Ex. 200

132 (1845), 153 E.R. 538,14 M. \& W. 418.
}

A sales slip may be drafted so as to constitute an agreement by the cardholder to reimburse the issuer. Whether such a sales slip is governed by the $B E A$ depends on whether it is a note. Thus, an acknowledgement of debt owed by the cardholder to the issucr is not a promisc to pay the debt. Whether it is conditional or unconditional, an acknowledgement is not a "promissory note." 133 At the same time, a promise to pay the issuer is a "promissory note," but only insofar as it is "unconditional." When such a "promissory note" payable to the issuer is delivered to the merchant, the latter may be viewed as an agent on behalf of the cardholder for the purpose of delivering it to the issuer through the acquirer. Alternatively, the merchant taking such a "promissory note" payable to the issuer may be viewed as a "remitter" who will then transfer it to the issuer. In the latter scenario, the merchant is in exactly the same position as a remitter of a bank draft or money order who purchases it for value from the issuing bank for transfer to the designated payee and who, by transferring it to the payee, pays the payee for goods or services the remitter thereby acquires from the payee.

A sales slip will not satisfy the $B E A$ requirements where it contains neither a promise nor order (as, for example, in the case of an acknowledgement of debt) and where either the order or promise is conditional. Indeed, it is possible to argue that the act of delivery by the cardholder to the merchant of a signed sales slip in whatever form, as a culmination of the card payment process, is an unconditional order issued by the cardholder to the issuer to pay. However, on its own, this is not a written and signed order.

Where the sales slip contains an order by the cardholder to the issuer side by side with a promise by the cardholder to pay the issuer "subject to and in accordance with the terms of the cardholder agreement,"134 the promise is "conditional" so as not to be a promissory note. Indeed, in such a case, on its own, and unlike the promise, the order may be read as not subject to the cardholder agreement. Nevertheless, arguably in such a case, the cardholder's order may be construed as conditional on the cardholder's reimbursement promise. Stated otherwise, the order may be read as instructing the issuer to make payment to the merchant in return for the cardholder's promise to reimburse it. This would be the case also when both the order and the promise are stated unconditionally. In such a case, the cardholder's reimbursement promise may also be read as subject to the issuer's complying with the order. Stated otherwise, a combined unconditional order and promise may render each to be conditional and dependent on each other. This, of course, may depend on the specific language of the sales slip, and yet there is a chance that a combined order and promise will be treated as dependent on each other.

${ }^{133}$ See e.g. Sheehan v. Mercantile Co. (1919), 45 O.L.R. 422 (Ont. H.C.) at paras. 22-23; reversed 1920 CarswellOnt 162, 52 D.L.R. 538, 46 O.L.R. 581 (Ont. C.A.).

${ }^{134}$ As was the case in, e.g., Harris Trust and Sav. Bank v. McCray, 316 N.E.2d 209 (Ill.App. 1 st Dist. 4th Div., 1974). The specific issue neither arose nor was dealt with by the court. 
There is another anticipated objection to viewing the sales slip as a bill or cheque, even where it is drafted to be an unconditional order. The argument is based on the fact that it is not envisaged that sales slips circulate and, hence, they are not "negotiable." My response is that, indeed, in the ordinary scheme of things, bills of exchange and promissory notes are negotiable. However, whether an instrument is a bill or note depends on compliance with formal statutory requirements and not on the intention of the parties. Moreover, many indisputably negotiable instruments are issued today with no intent whatsoever that they will circulate. Such is the case for most cheques and possibly for notes issued for bank loans. Furthermore, the negotiability of bills, cheques, and notes can be negated by the maker of a note or drawer of a bill or cheque and the instrument will nevertheless remain governed otherwise by the $B E A{ }^{135}$

At present, instructions for a credit card payment are mainly given electronically. As well, they can be communicated by mail, in which case the language is not standardized. They can also be provided by phone, in which case they are neither written nor signed. Neither electronic nor telephone order is a bill of exchange, cheque, or promissory note. Whether a mail order qualifies depends on its language. Similarly, instructions for a card payment communicated over the Internet do not involve a written and signed document. On the basis of the present understanding of what constitute a bill or cheque, an electronic instruction cannot be viewed as such.

May Parliament decide to modify the definition of "cheques" (or even "bills") and enlarge it to cover more and even all types of payment orders? It is noteworthy that Parliament already significantly expanded the scope of "cheques" by redefining "bank" to ultimately include any CPA member, not even necessarily a deposit-taker. ${ }^{136}$ Presumably then, it will be difficult to challenge the power of Parliament to eliminate the medium restrictions on which cheque orders are to be issued and provide for "electronic cheques,"137 such as the Interac email transfer. ${ }^{138}$ What may, however, be counterintuitive is the inclusion in "cheques" of payment orders initiating credit transfers. ${ }^{139}$

135 See e.g. BEA, supra note 31 , ss. $20(1)$ and 174

136 Specifically, under $B E A$, ibid., s. 165(1), "A cheque is a bill drawn on a bank, payable on demand." For that purpose alone, "bank" is broadly defined in $B E A$, s. 164 by reference to Canadian Payments Association membership to which non-bank deposit-taking institutions and non-deposit-taking financial intermediaries also may qualify. See Canadian Paynents Act, R.S.C. 1985 , c. C-21, s. 4.

137 Namely, an electronic payment order issued directly to the payee that can be negotiated and deposited to an account like a paper cheque. It is also known as an electronic payment order (EPO).

${ }^{138}$ For a description of the service and system, see Crawford, Banking and Payment, vol. 2, supra note 117, s. 16:60.30(1). The system is operated and cleared by Acxsys Corporation and settled over either the LVTS or bilateral netting but not over the ACSS.

139 Discussed at the beginning of Part 3, following the discussion on The Brimnes, supra note 105.
Be that as it may, the argument in Marcotte v. Fédération ${ }^{140}$ went beyond a mere reliance on the language of the sales slip. Rather, it was argued that "payment by credit card is analogous to payment by bill of exchange" so as to trigger exclusive federal jurisdiction under section 91(18) of the Constitution Act. The analogy was premised on the fact that the merchant can present the sales slip to the card issuer "to receive hard currency." The Supreme Court of Canada understood this reasoning to lead to the conclusion that "payment methods such as gift cards and coupons would also seem to be classified as bills of exchange" 141 and rejected it altogether: ${ }^{142}$

This is not a case, as Desjardins argues, where the changed social circumstances in Canada, namely the increased popularity of payment by credit card as opposed to payment by cheque, would justify reinterpreting s. 91(18) of the Constitution Act, 1867 so as to include credit cards. "Bills of exchange" is a well-established technical term around which an extensive structure of legislation, notably the Bills of Exchange Act, has developed. Although this Court has recognized that the Canadian Constitution must be "capable of adapting with the times by way of a process of evolutionary interpretation", that evolution must remain "within the natural limits of the text" (Canada (Attorney General) v. Hislop, 2007 SCC 10, [2007] I S.C.R. 429, at para. 94). There has been no shift in how the term "bills of exchange" is defined in Canada. While some of the effects of payment by credit card are the same as payment by bills of exchange, the natural limits of the text of $s$. $91(18)$ of the Constitution Act, 1867 prevent it from being reinterpreted to include credit cards.

The analysis in Part 2(a) of this article above supports this conclusion. However, I respectfully submit that it did not fully meet Desjardins' argument. What was argued was not a redefinition of "bill of exchange" but rather an adjustment or adaptation of the "bills and notes" legislative power under section 91(18) of the Constitution Act. Effectively, the argument aimed at reading this provision as covering all payment orders and not being limited to "bills" no matter what the latter is interpreted to mean. So understood, the argument is premised on the fact that, at the time the Constitution passed, payment orders were mostly if not exclusively paper cheques or other bills of exchange so that what the drafters had in mind was to capture all payment methods. Had the Court accepted the argument, all types of payment orders, paper and electronic, initiated by card, telex, or otherwise, could have fallen within the federal "bills and notes" power under section 91(18) of the Constitution Act.

The irony is that while, this analysis strikes as "progressive interpretation" of the Constitution, as a matter of fact it also reflects its "original understanding." This brand of "originalism" is not premised on treating "bills and notes" as

140 Supra note 118 (SCC).

141 Ibid. at para. 18.

142 Ibid. at para. 20. 
"frozen concepts." 143 Rather, it focuses on the drafters' likely original intention to capture the whole range of payment methods - as they keep emerging and developing.

\section{DEPOSIT-TAKING AND LEGISLATIVE POWER IN RELATION TO PANTKING}

The "bills and notes" legislative power covering cheques as payment instructions reaches the customer-to-customer, customer-to-PSP, and PSP-toPSP domains with respect to them. It may, however, be far-fetched to see this power extending to the customer-PSP/bank contractual relationship governing cheque use. The organization and regulation of the clearing and settlement system for cheques also appear to fall outside the "bills and notes" power. Whether such matters fall under federal jurisdiction requires an examination of the legislative power relating to "banking."

Under Section 91(15) of the Constitution Act, "all Matters coming within" "Banking, Incorporation of Banks, and the Issue of Paper Money" are assigned "the exclusive Legislative Authority of the Parliament of Canada ..." Discussing the scope of "[t]he legislative authority conferred by these words," Tennant $v$. Union Bank of Canada (1893) held that "banking" is "an expression which is wide enough to embrace every transaction coming within the legitimate business of a banker." " 44 Under this reasoning, a federal statute dealing with a transaction that an incorporated bank was authorized by law to make was held valid. This is so notwithstanding the fact that, by its nature, such legislation addressed "Property and Civil Rights in the Province," a subject assigned by Section 92(13) to exclusive provincial jurisdiction. ${ }^{145}$ Subsequently, it was also held that "Banking" in section 91(15) is not limited to the extent and kind of business carried on by banks in Canada in $1867 .^{146}$

However, this broad legislative power was taken to underlie an "institutional" approach. ${ }^{147}$ Thereunder, according to Canadian Pioneer Management Ltd. v. Saskatchewan (Labour Relations Board) (1980), ${ }^{148}$

143 Quoted terms are from Hogg, supra note 28 at 15-59.

144 (1893), 1893 CarswellOnt 35, [1894] A.C. 31, C.R. [10] A.C. 387, 5 Cart. B.N.A. 244 (Jud. Com. of Privy Coun.) at para. 29.

145 Overlap of jurisdictions is recognized under the "double aspect doctrine" pronounced in Hodge \%. Oueen, The (1883), 9 App. Cas. 117 at 130 . However, under what came to be known as "federal paramountcy," "where there are inconsistent (or conflicting) [competent] federal and provincial laws, it is the federal law which prevails." See Hogg, supra note 28 at 16-2 to $16-3$.

146 Reference re Bill of Rights Act (Alberta), 1947 CarswellAlta 42, [1947] 4 D.L.R. 1, (sub nom. Alberta (Attorney General) v. Canada (Attorney General)) [1947] 2 W.W.R. 401, [1947] A.C. 503, [1947] L.J.R. 1392, 63 T.L.R. 479, [1947] J.C.J. No. 5 (Jud. Com. of Privy Coun.) at 9 [D.L.R.].

147 Those arguing that Tennant $v$. Union Bank stands for a functional approach, e.g., Darcy Readman \& Steve Laird, "The Constitutionality of the Alberta Treasury Branches" "banking" is said to involve "a set of interrelated financial activities carried out by an institution that operates under the nomenclature and terms of incorporation which clearly identify it as having the distinctive institutional character of a bank." Thus, whether a given set of interrelated financial activities carried falls "within the concept of banking as a business" 149 depends on whether they are carried out by an institution incorporated as a bank or by a non-bank trust company; the answer is positive in the former case and negative in the latter.

For certain, the "banking" power extends to all aspects of payment law in relation to federally chartered banks. However, at first blush, it seems to follow that a business activity carried out by a trust company - in fact, by any nonbank entity - that duplicates that of banks is not "banking" and thus is outside the federal legislative power relating to "banking." However, upon reflection, such a conclusion does not necessarily follow from Pioneer. The case concerned a challenge to provincial jurisdiction over labour relations in a trust company. The latter argued that it carries on a banking business and thus fell outside the reach of the Provincial Legislature. In his judgment, Beetz J. noted that the interpretation of Section 91(15) of the Constitution Act discussed above followed both the "approach taken by Parliament" and its application by courts, rather than an inherent limitation in the section. ${ }^{150}$ Furthermore, he went on to say that the institutional approach "is particularly helpful in a case where what has to be decided is whether a given institution falls within the concept of banking as a business, and not whether a legislative enactment is constitutionally depending on its relationship to banking within the meaning of s. 91, head 15 of the constitution". More generally, "[t] he concept of banking as a business 151 and the meaning of the word 'banking' in s. 91 , head 15, are not necessarily coextensive; the meaning of 'banking' in the section might very well be wider than the concept of banking as a business." 152

Stated otherwise, Pioneer does not preclude the extension of "banking" in section 91(15) of the Constitution Act to activities carried out by non-bank entities. In his separate judgment, Laskin C.J.C. specifically noted "the failure or unwillingness of Parliament to legislate to the full limit of its powers"153 and did

(1998) 2 CBR (4th) 139 at 143, overlook the fact that Tennant v. Union Bank dealt only with transactions carried out by those determined as banks under an institutional test.

148 (1979), 1979 CarswellSask 163, 1979 CarswellSask 159, [1980] 1 S.C.R. 433, 107 D.L.R. (3d) 1, [1980] 3 W.W.R. 214, 80 C.L.L.C. 14, 018,31 N.R. 361, 2 Sask. R. 217 (S.C.C.) at para. 71, adopting the position presented by the Attorney General of New Brunswick.

149 Ibid. at para. 75.

150 Ibid. at paras. 73-74.

151 For speculation on the difference between "banking business" and "business of banking" under banking legislation in Canada, see e.g. Gillian Lester, "The Regulation of Foreign Banks in Canada: Milelli Marks a Decade of Ambiguity" (1991) 17 Can. Bus. L.J. 430 at 435-444. See also C.C. Johnston, "Judicial Comment of 'Banking Business", (1962) 2 Osgoode Hall Law Journal 347.

152 Pioneer, supra note 148 at para. 75 
not rule out the possibility that "Parliament could have brought trust companies within its regulatory authority in relation to banking" but."has chosen not to do so." 154 In turn, Beetz J. acknowledged the difficulty of defining banking, which is not a legal term, but rather a term evoking "economic notions which are notoriously not amenable to the discipline of the law."155

By reference to Laskin C.J.C.'s question in Pioneer, what are "the full limits of [federal Parliament's] power"156 in relation to "banking"? Primarily, the search here is for the full extent of the federal power that would supersede conflicting even if otherwise valid provincial law, rather than for only the core of the federal power that could have precluded any validity from a conflicting piece of provincial legislation. ${ }^{157}$

For the purpose of this article, what matters is whether payment transactions and providers of payment services fall within the ambit of the banking legislative power under section 91(15) of the Constitution Act. Besides federally chartered banks, providers of such payment services may be other types of regulated financial intermediaries - as well as other entities, particularly money transmitters, a term used here to cover all non-financial intermediaries who provide funds transfer or payment services (namely, facilitating non-cash payments) to end users. In effect, whether money transmitters are to be regulated and, if so, to what extent, is part of the broader emerging question: that is, the regulation of shadow-banking. ${ }^{158}$ However, the route taken here is the examination of the "full limits" only in connection with payment transactions and payment service providers. At the same time, payment system participants are not only front-end providers such as banks, other financial intermediaries, and money transmitters. They also include back-end providers such as processors as well as operators of retail payment infrastructure. ${ }^{159}$ To the extent that they

153 lbid. at para. 3.

154 Ibid. at para. 6.

155 Ibid. at para. 33

156 Ibid. at para. 3.

157 Another way to put it is that the search here is for "Paramountcy" and not "Interjurisdictional Immunity," as pronounced by Bastarache J. in Canadian Western Bank v. Alberta, 2007 SCC 22, 2007 CarswellAlta 702, 2007 CarswellAlta 703, [2007] 2 S.C.R. 3, 409 A.R. 207, 75 Alta. L.R. (4th) 1, 49 C.C.L.I. (4th) 1, 281 D.L.R. (4th) 125 [2007] 8 W.W.R. 1, [2007] I.L.R. I-4622, 362 N.R. 111, 402 W.A.C. 207, [2007] S.C.J. No, 22 (S.C.C.) at para. 114.

158 "Shadow banking, as usually defined, comprises a diverse set of institutions and markets that, collectively, carry out traditional banking functions - but do so outside, or in ways only loosely linked to, the traditional system of regulated depository institutions." B.S. Bernanke, "Rethinking Finance" (Speech delivered at the Russell Sage Foundation and The Century Foundation Conference, 13 April 2012), online: < http://www.federalreserve.gov/newsevents/speech/bernanke20120413a.htm >.

159 See e.g. Committee on Payments and Market Infrastructures (CPMI), Non-Bank in Retail Payments (Basle: Bank for International Settlement, 2014) at 9 act for front-end players, it is assumed that they fall under the jurisdiction that is competent by reference to the front-end player itself.

"Full limits" of "banking" in relation to payment transactions and service providers are first to be explored by reference to the history of the banking legislative power in the context in which it was passed. To that end, it was observed that "the main trajectory of the law has been to honour the original expressed intention of 1867 of ensuring a strong federal jurisdiction over matters relating to the national economy, including banks." 160 What are then "the full limits" under the "original expressed intention"? According to Binavince and Fairley, ${ }^{161}$

At Confederation, the Founding Fathers had in mind an orderly and uniform financial system for the new Dominion, subject to national jurisdiction and control. Conventional wisdom suggests that the Constitution Act, 1867 reflected this governing assumption in granting to the exclusive jurisdiction of Parliament the subject matter of "Banking, Incorporation of Banks and the Issue of Paper Money" pursuant to section 91(15). Corollary heads of legislative power placed 1867 conceptions of the monetary and financial system unequivocally in federal hands.

"Corollary heads of power" specifically enumerated by the authors ${ }^{162}$ are "Saving Banks" (s. 91(16)); "Bills of Exchange and Promissory Notes" (s. 91(18)), "Interest" (s. 91(19)); "Legal Tender" (s. 91(20)); and "Bankruptcy and Insolvency" (s. 91(21)). I should add also "Currency and Coinage" (s. 91(14)). ${ }^{163}$

In Reference re Alberta Legislation, ${ }^{164}$ Hudson J. of the Supreme Court of Canada observed that, when these heads of federal jurisdiction ${ }^{165}$ are read together, the cumulative effect is much greater than if the individual heads are considered separately. ${ }^{166}$ Along these lines, it is arguable that, inasmuch as

160 Margaret H. Ogilvie, "Canadian Western Bank v. Alberta: Cooperative Federalism and the end of 'Banking"' (2008-09) 47 Can Bus LJ 75 at 75.

161 Emilio S. Binavince \& H. Scott Fairley, "Banking and the Constitution: Untested Limits of Federal Jurisdiction" (1986) 65:1 Can Bar Rev 328 at 329.

162 Ibid.

${ }^{163} \mathrm{Cf}$. powers listed by Ogilvie, Bank and Customer Law, supra note 116 at 8 who adds the Regulation of Trade and Commerce (under s. 91(2)) but omits Bankruptcy and Insolvency (under s. 91(21).

1641938 CarswellAlta 88, [1938] S.C.R. 100, [1938]2 D.L.R. 81, [1938] S.C.J. No. 2 (S.C.C.) at para. 201; affirmed (1938), 1938 CarswellAlta 92, (sub nom. Alberta (Attorney General) v. Canada (Attorney General)) [1938] 4 D.L.R. 433, [1938] 3 W.W.R. 337, [1939] A.C. 117, 108 L.J.P.C. 1, [1938] W.N. 349 (Jud. Com. of Privy Coun.).

165 Namely, by reference to powers listed in s. 91 of the Constitution Act, supra note $15^{\text {" }}(2)$ The regulation of trade and commerce; (14) Currency and coinage; (15) Banking, incorporation of banks and the issue of paper money; (16) Savings banks; (18) Bills of exchange promissory notes; (19) Interest; [and] (20) Legal tender."

166 On this point see: Terence D. Hall, "Bank Promotion of Insurance: Canadian Western Bank v. Alberta" (2004) 19 BFLR 457 at 465. 
federal jurisdiction explicitly covers money, cheques, and banking, it implicitly extends to cover the entire PSP-to-PSP domain - that is, the clearing and settlement of payment items - as well as all methods of transfers of monetary valuc, as they keep evolving, that are essential to the proper functioning of a modern national money economy. Along more concrete lines, it is also arguable that under "progressive interpretation"167 the 19th-century power over bills, cheques, and various forms of money is to be construed in the 21 st century as extending to all payment mechanisms initiated, in the footsteps of the bill and cheque, by an order. After all, the Constitution "is a living tree which, by way of progressive interpretation, accommodates and addresses the realities of modern life." 168

Indeed, in the pursuit of a national financial system, Parliament has proven that it can be assertive. On the whole, this assertiveness has been well received. For example, in Re Alberta Legislation, ${ }^{169}$ Hudson J. stated by reference to the Preamble of an Act of Parliament establishing a central bank for Canada that:

It is interesting to observe that the Bank of Canada Act, 1934 (Dominion), establishes a central bank 'to regulate credit and currency in the best interests of the economic life of the nation, to control and protect the external value of the national monetary unit and to mitigate by its influence fluctuations in the general level of production, trade, prices and employment so far as may be possible within the scope of monetary action, and generally to promote the economic and financial welfare of the Dominion.' No one doubts the constitutionality of this Act ...

More recently, in the Preamble to the Payment Clearing and Settlement Act $(P C S A){ }^{170}$ the drafters explained that "the clearing and settlement of payment obligations among financial institutions are an essential element of the financial system in Canada." Federal jurisdiction with respect to them was assumed in the name of "the national interest" and the role of the Bank of Canada "in promoting the economic and financial welfare," in order to achieve "the stability of the financial system in Canada and the maintenance of efficient financial markets," as well as "in order to control risk to the financial system in Canada

167 According to Hogg, supra note 28 at $15-49$, specifically rejecting the "frozen concepts" underlying the theory of "originalism" to the contrary, "the doctrine of progressive interpretation is one of the means by which the Constitution Act, 1867 has been able to adapt to changes . .." at 15-48.

168 Reference re Same-Sex Marriage (2004), 2004 CSC 79, 2004 SCC 79, 2004 CarswellNat 4422, 2004 CarswellNat 4423, REJB 2004-81254, [2004] 3 S.C.R. 698, 246 D.L.R. (4th) 193, 12 R.F.L. (6th) 153,125 C.R.R. (2d) 122, 328 N.R. 1, [2003] S.C.C.A. No. 325, [2004] S.C.J. No. 75 (S.C.C.) at para. 22. For this phrase see also text that follows note 29, supra.

169 Supra note 164 at para. 202

${ }^{170}$ S.C. 1996 , c. 6, Sch., Preamble. and contribute to its stability." Needless to say, none of these is an express head of federal legislative power under the Constitution Act.

Neither the original Canadian Payments Association Act ${ }^{171}$ nor its revised version as the Canadian Payments $A c t^{172}$ has a Preamble. Having reviewed background papers, Crawford ${ }^{173}$ concludes that the fundamental policies of efficiency and safety served as the basis for those provisions of the Canadian Payments Act dealing with payment systems that do not necessarily involve a systemic risk to the Canadian financial system. In his opinion, federal jurisdiction can be rationalized also with respect to such systems, since they "must be operated prudently and responsibly in order to maintain public confidence in electronic payment systems." 174

He is also of the view ${ }^{175}$ that "[p]rotection of the payment system by the reduction of risks created by participants' insolvency appears . . . to be a legitimate topic for federal legislation even if its provisions impinge somewhat on ... civil rights . .." He goes on to assert that:

In the Preamble to the PCSA, the federal government seems to be signalling its intention to lay claim to the right to legislate in the national interest with respect to the payment clearing and settlemen systems of significance to the Canadian financial system, perhaps as an exercise of its power over banking, perhaps in relation to insolvency, or perhaps (in view of the express references to the national interest and the national economy) under the residual "peace, order and good government" power. ${ }^{176}$

A recent amendment to the $P C S A$ expanding the power of the Governor of the Bank of Canada to address "payment system risk" in clearing and settlement systems confirms this approach. ${ }^{177}$ Subsequently, in a consultation document, ${ }^{178}$ the government of Canada pointed out that under Part 2 of the Canadian

171 S.C. $1980-81-82-83$, c. 40, s. 54

172 S.C. 2001 , c. 9, s. 218

173 Bradley Crawford, The Law of Banking and Payment in Canada, vol. 1, looseleaf (Toronto: Canada Law Book, 2008) at s. 7:50.30(1).

174 Ibid., s. 7:40.

175 Ibid., s. 7:50.30(2).

176 Ibid., s. 7:50.30(1).

177 PCSA supra note 170 , as amended 2014 , c. 39 , s. 362 " "Payments system risk" is defined in $s .2$ to mean:the risk that a disruption to or a failure of a clearing and settlement system could cause a significant adverse effect on economic activity in Canada by $(a)$ impairing the ability of individuals, businesses or government entities to make payments, or $(b)$ producing a general loss of confidence in the overall Canadian payments system, which includes payment instruments, infrastructure, organizations, market arrangements and legal frameworks that allow for the transfer of monetary value.

178 Department of Finance of Canada, Balancing Oversight and Innovation in the Ways We Pay: A Consultation Paper (13 April 2015), online: < http://www.fin.gc.ca/activty/ consult/onps-ssnp-eng.asp $>$ at 5 . 
Payments Act" 179 the government "has responsibilities with respect to the oversight and regulation of payment systems that are national or substantially national in scope, or systems that play a major role in supporting transactions in Canadian financial markets or the Canadian economy." Arguably, it is along these lines that even the earlier passage by Parliament of the Payment Card Network Act ${ }^{180}$ can be rationalized. The latter authorizes regulations to effectively address the contractual relationships between cardholders and card issuers. 181

For its part, the "orderly and uniform financial system for the Dominion" of which Binavince and Fairley speak ${ }^{182}$ is likely to include all financial intermediaries, such as all those belonging to the historical "four pillars": namely, in addition to banks, also trust and loan companies, securities firms, and insurance companies. ${ }^{183}$ Arguably, it is along these lines that Crawford explains the indiscriminate application of the Prepaid Payment Products Regulations ${ }^{184}$ to all federally regulated financial institutions as premised on "banking" being viewed as a federally regulated activity, even as it is carried out by non-banks. ${ }^{185}$ This is, however, only a limited breakaway from the institutional approach since, as Crawford concedes, "extraordinarily extensive statutory authority" from "all the federal financial institutions statutes" is invoked as the basis of these regulations. ${ }^{186}$ Being limited to an activity carried out by federally regulated financial institutions, this approach ought not to be taken as marking "the full limits of [federal Parliament's] power"187 in relation to "banking."

So far, no power in relation to non-federally regulated financial intermediaries has been claimed by the federal government. ${ }^{188}$ In any event,

179. Supra note 172. Part 2 of the Act authorizes the Minister to designate a payment system that is national or substantially national in scope, or that plays a major role in supporting transactions in Canadian financial markets or the Canadian economy.

${ }^{180}$ S.C. 2010 , c. 12 , s. 1834

181 Particularly, see 6(d). Once in force, it gives effect to regulations "prescribing conditions regarding the issuance of payment cards that a payment card network operator must include in any agreement entered into with an issuer."

182 Stipra note 161 at 329 ; and accompanying text.

183 See e. Christopher C. Nicholls, Financial Institutions: The Regulatory Framework (Canada: LexisNexis Canada, 2008) at 11 .

184 S.O.R./2013-209.

185 Bradley Crawford, "The Prepaid Payment Products Regulation: The Feds are Coming" (2014) 29 B.F.L.R. 549 at 551.

186 Ibid. at 550

187 Per Laskin C.J.C. in Pioneer, supra note 156

188 See e.g. W.D. Moull, E.J. Waizer \& J. Ziegel, "The Changing Regulatory Environment for Canadian Financial Institutions: Constitutional Aspects and Federal--Provincia Relations" in Jacob Ziegel, Leonard Waverman \& David W. Conklin, Canadian Financial Institutions: Changing the Regulatory Environment (Toronto: Ontario Economic Council, 1985) at 101. even if it were claimed to the entire extent of the activity of financial intermediation, this power is not broad enough to embrace those providers of payment services that are not truly financial intermediaries, such as money transmitters.

I therefore submit that the key to an expanded federal jurisdiction is inquiry into the meaning of "banking" functionally, that is, by examining the activities of which banking consists. Historically, the meaning of "banking" has not been constant throughout the generations. Deposit banking, in the sense of accepting deposits and lending them, goes back in Antiquity to both Greece ${ }^{189}$ and Rome. ${ }^{190}$ In Europe, it declined and ultimately became dormant towards the end of the fifth century CE, when Antiquity came to end. "Banking" reappeared in the first part of the second millennium and developed during the late Middle Ages. However, "banking" in Medieval Europe covered both exchange and deposit banking; these were separate businesses, generally speaking, carried out by different persons. Exchange bankers were large merchants forming extensive intercity networks. At the same time, deposit and transfer bankers emerged, as an outgrowth of local money-change business, as of the late part of the 12th century. They operated until the first part of the 16th century. During that period, they accepted deposits, gave loans out of them, facilitated book transfers, and sometimes provided chequing services. In the course of the 16th century, they disappeared. To a large extent, their functions were taken over by public banks, except that the latter were restricted in, if not precluded altogether from, making loans and otherwise extending credit. Public banks continued to exist until the end of the 18 th century. ${ }^{191}$

According to De Roover, "[i]n all the manuals of the seventeenth and eighteenth centuries, a banker is defined as a dealer in bills of exchange who

189 See e.g. Raymond Bogaert, Banques et banquiers dans les cités grecques (Leyde: A.W. Sijthoff, 1968) at 50-60 and 331-345; and E.E. Cohen, Athenian Economy and Society: A Banking Perspective (Princeton, N.J.: Princeton University Press, 1992) at 8-11, 14-18, 62-66, and 111-121.

190 See e.g. Jean Andreau, Banking and Business in the Roman World, trans. by Janet Lloyd (Cambridge: Cambridge University Press, 1999) at 30-49. See also Dominic Rathbone \& P. Temin, "Financial Intermediation in First-Century AD Rome and EighteenthCentury England" in K. Verboven, K. Vandorpe \& V. Chankowski, eds., Pistoi Dia Tèn Technen - Bankers, Loans and Archives in the Ancient World: Studies in Honour of Raymond Bogaert (Leuven: Peeters, 2008) at 371.

191 For Medieval banking, see e.g. Raymond Adrien De Roover, "Banking and Credit in the Formation of Capitalism" (Paper presented at the Fifth International Conference of Economic History Leningrad, 1970), (Paris, 1979) at 9; and in more detail, R. De Roover, Money, Banking and Credit in Mediaeval Bruges: Italian Merchant Bankers, Lombards and Money Changers: A Study in the Origins of Banking (Cambridge, Mass.: The Mediaeval Academy of America, 1948), republished as vol. 2 of The Energence of International Business, 1200-1800 (London: Routledge/Thoemmes Press, 1999). For public banks, see e.g. J.G. Van Dillen, ed., History of the Principal Public Banks (London: Frank Cass, 1964), which is a reprint of the original 1934 edition (The Hague: Martinus Nijhoff, 1934). 
operates with correspondents abroad and speculates on the rates of exchange." 192 For its part, modern commercial banking emerged as of the 18 th century in England; it merged (i) a new way for dealing with bills of exchange (i.e., discounting rather than participation in an exchange transaction), (ii) a renewed practice of deposit-taking for lending as well as the provision of chequing services (both paying and collecting them out of and into depositors' current accounts), and (iii) a novel function, that of the issue of banknotes as paper money. Over the years, modern commercial banking lost its bill of exchange dealing and banknote issue functions. ${ }^{193}$ In 1914, Issacs J. in the High Court of Australia said that:

[T] $\mathrm{T}$ e essential characteristics of the business of banking . . . may be described as the collection of money by receiving deposits upon loan, repayable when and as expressly or impliedly agreed upon, and the utilization of the money so collected by lending it again in such sums as are required. ${ }^{194}$

In United Dominions Trust Ltd. v. Kirkwood (1966), Lord Denning MR accepted this definition and further elaborated:

There are ... two characteristics usually found in bankers today: (i) they accept money from, and collect cheques for, their customers and place them to their credit; (ii) They honour cheques or orders drawn on them by their customers when presented for payment and debit the customers accordingly. These two characteristics carry with them also a third, namely: (iii) They keep current accounts, or something of that nature, in their books in which the credits and debits are entered. ${ }^{195}$

This cumulative definition of the core of the "banking business" was followed in Canada; ${ }^{196}$ it still holds true, albeit subject to modifications recognizing the advent of electronic banking and the emergence of modern payment methods other than the cheque. ${ }^{197}$ It is consistent with the perspective of economists who view the core services of the modern commercial banker as

192 See e.g. Raymond Adrien De Roover, "New Interpretations of the History of Banking" in Julius Kirshner, ed., Business, Banking, and Economic Thought in Late Medieval and Early Modern Europe: Selected Studies of Raymond de Roover (Chicago: University of Chicago Press, 1974; Phoenix Edition, 1976) at 200, 229.

${ }^{19.3}$ In general, see e.g. Richards, The Early History of Banking, supra note 35.

${ }_{194}$ State Savings Bank of Victoria v. Permewan, Wright \& Co. (1915), 19 C.L.R. 457 at 471.

195 [1966] 2 Q.B. 431 (Eng. C.A.) at 447.

196 It was cited with approval (as a matter of common law) by Beetz J. Pioneer, supra note 148, wherc he concluded at paras. 51-54 as to any definition of banking business that "issuing letters of credit ... lending money; and . . . accepting. . . term deposits ..." are within what, in common knowledge, would be considered "[t]he hard core of banking."

197 See Eliahu Peter Ellinger, Eva Lomnicka \& Richard Hooley, Ellinger's Modern Banking Law, 4th ed. (Oxford: Oxford University Press, 2006) at 69-73, where it is pointed out (at 73) that, as stated, the definition "concentrates too much on the precise mechanisns by which money is paid into and out of bank accounts." consisting of deposit taking, lending, and providing payment facilities. ${ }^{198}$ Indeed, "[t]o be recognized as a bank . . . an institution is expected to receive deposits of money from its customers; to maintain current accounts for them; to provide advances in the form of loans or overdrafts; and to manage payments on behalf of its customers." 199

On its own, neither lending nor providing payment services is "banking." What makes institutions into "banks" in the broad common law and economic sense is deposit-taking. Nevertheless, as a business, deposit-taking does not stand on its own. "From an economic point of view the banking function may be defined as the provision of services which facilitate the creation of bank deposits (i.e., bank money). Bank services which do not aid in the provision of bank deposits would be defined as non-banking services." 200 Indeed, on its own, deposit-taking for mere safekeeping is expensive and hence inefficient.

The provision of payment services is ancillary to the basic banking function of deposit-taking. Indeed, where both payer and payee have funds on deposit, it is efficient to have the payer pay the payee by means of book entries to their respective accounts. In turn, it is the availability of deposited funds for lending to third parties that makes deposit-taking profitable to a depositary. Hence, deposit-giving becomes cost-efficient to the depositor, to whom the depositary will pass some of the profits, in the form of cost savings, with the view of attracting more deposits. Thus, the evolution in Antiquity ${ }^{201}$ of mechanisms for payments initiated by the issue of payment orders had been part and parcel of the emergence of "banking" as a form of financial intermediation between depositors to and borrowers from the depositary. Indeed, incentives for keeping money with depositaries and using it for making payments to third parties exist even where the depositary does not lend out of them in his own name; historically, also a depositary who did not lend provided payment services. Nevertheless, in the long run, the process of taking deposits, lending them, and allowing them to be used by the depositors in payment to third parties turned the depositary into a bank. ${ }^{202}$

While the bank deposit is typically entered into a running account to which deposits and withdrawals are posted, its legal underpinning goes to Bretton v.

198 Jonathan Law et al., eds., A Dictionary of Finance and Banking (Oxford: Oxford University Press, 2008) s.v. "bank"; Christopher T.S. Ragan \& Richard G. Lipsey, Economics, 12th ed. (Toronto: Pearson Addison Wesley, 2008) at 654; Stephen L. Slavin, Economics, 6th ed. (Boston: McGraw-Hill Irwin, 2002) at 355, 357.

199 See e.g. Edwin Green, Banking - An Illustrated History (New York: Rizzoli, 1989) at 11.

200 Jack Carr, Arthur Milne \& Stuart M. Turnbull "Greenline Investors Service: Shall We Keep Brokers and Banks Apart?" (1983-84) 8 Can. Bus. L.J. 257 at 267.

201 Roughly speaking, Antiquity comes to an end with the beginning of the Middle Ages, usually marked by the fall of Rome in $476 \mathrm{CE}$.

202 For an insight into the process, though well into the later Medieval period, see e.g. Abott Payson Usher, The Early History of Deposit Banking in Mediterranean Europe, Vol. 1 (Cambridge, Mass.: Harvard University Press, 1943) particularly at 3-25. 
Bamet (1598) ${ }^{203}$ This case dealt with the situation in which "[a] man delivers money to J.S. to be redelivered to him when he should be required: which J.S. refused." 204 The deliverer brought a debt action against J.S. Particular emphasis was given to the distinction bctween "debt" and "detinue"; namely, between an action for a sum of money and an action for the return of specific coins. ${ }^{205}$ Explicitly citing a case holding that where "a man delivers money to another to buy certain things for him, and he does not buy them, the party may bring an action of debt ...", 206 the Court held for the plaintiff. It is on this basis that, in Foley v. Hill (1848), the House of Lords held that "a banker . . receiving money from his customer on condition of paying it back when asked . . "207 "is a debtor" to the customer. ${ }^{208}$ Hence, a single-purpose deposit for either safekeeping or payment to a third party is deposit-taking and hence subject to the legislative power with respect to it. Furthermore, for the purpose of regulatory powers, albeit not necessarily for all intents and purposes, even a prepayment for goods and services to be acquired at the discretion of the payer from a single retailer by means of a prepaid close-loop prepaid card is considered a "deposit."

Viewing the scope of the federal legislative power in relation to "banking" as premised on the meaning of the "banking business" or the function of "banking" as deposit-taking is not a novel idea in the constitutional discourse in Canada. In 1964, the Porter Commission defined "banking liabilities" as "claims which serve as means of payment or close substitutes for them."209 Accordingly, it observed that the "banking function is generally taken to include the issuing of claims

203 (1598), 74 E.R. 918 Owen 86 (Eng. K.B.).

$204 \mathrm{Ibid}$. Notwithstanding the ambiguity in this statement of facts, the report unequivocally suggests (and so it was understood by Alfred William Brian Simpson, A History of the Conmon Law of Contract: The Rise of the Action of Assumpsit (Oxford: Clarendon Press, 1975) a 183) that the case dealt with the deposit of money for safekeeping, and not with demand loan. It is unlikely that a borrower's debt liability would have been disputed in 1599.

205 The earliest writs for the recovery of a specific sum of money as well as a specific chatte under the common law of England were modelled on the praecipe writs, namely the Writs Right for the recovery of land. Around the closed they formed a composite writ originally encompassing debt and detinue. The ultimate split occurred towards the end of the 13th century. Debt had come to provide for the recovery of a specific sum of money. Detinue had come to provide for the recovery of specific goods. See in general Stroud Francis Charles Milsom, Historical Foundations of the Common Law, 2d ed (Toronto: Butterworths, 1981) at 262-65; Cecil Herbert Stuart Fifoot, History and Sources of the Common Law: Tort and Contract (London: Stevens \&
Sons, 1949) at 25-28, 217-18. See also Theodore Frank Thomas Plucknett, $A$ Concise History of the Common Law, 5th ed. (Boston: Little, Brown: 1956) at 363-65. Recovery of a specific amount of fungible (i.e., unascertained) goods fell under debt.

206 Cf. Core's Case (1537), 1 Dy. 19, 73 E.R. 42 (Eng. K.B.); Fifoot, ibid. at 285.

207 (1848), 9 E.R. 1002, 2 H.L. Cas. 28 (U.K. H.L.) at 43 [H.L. Cas.], at 1008 [E.R.]. A slightly earlier authority is Pott, Assignees of Joln Ryle, a Bankrupt v. Clegg, Executor of William Turner, Deceased (1847), 153 E.R. 1212; 16 M. \& W. 321

208 Ibid. at 37 (H.L. Cas.), 1006 (E.R.) which serve as means of payment or as close substitutes for such money claims." 210 On this basis, the Commission specifically recommended that, in principle, federal banking legislation "should encompass all financial institutions issuing demand liabilities, transferable and short-term deposits, and other shortterm banking claims." 211

Certainly, however, the Porter Commission had in mind only "financial intermediaries issuing claims which may be transferred immediately or on short notice by cheques or on customers' orders." 212 Its overall mandate was the regulation of the financial system; ${ }^{213}$ while it addressed (in Chapter 11) sales finance and consumer loan companies, it did not address money services including money transmitters. However, the Porter Commission aimed at a comprehensive "banking" regulation covering all deposit-taking financial intermediaries. In this context, it cannot be faulted for overlooking money transmitters. For certain, it is not proposed here to subject money transmitters that are not financial intermediaries to the full extent of banking regulation. Rather, the point stressed here is that, in the view of the Porter Commission, the distinguishing feature or the core of the "banking function is generally taken to include the issuing of claims which serve as means of payment or as close substitutes for such money claims."

It is then the taking of deposits which are used as a reservoir for non-cash payments that is the distinctive feature of "banking," setting it aside as a subject for regulation. It is certainly up to the legislature or regulator to divide deposittakers into categories and subject them to varied degrees of regulation. Indeed, as already mentioned in this Part, the post-Medieval public banks took deposits that were not lent but nevertheless were used as a reservoir for non-cash payments. Of course, in this day and age, it is absolutely legitimate to limit by law the use of the word "bank" to a deposit-taker that is pretty much free to lend and use deposited funds as it pleases. This is, however, not to deny that the taking of deposits that are used as the reservoir for non-cash payments by other institutions not legally called "banks" is nevertheless "banking" for the purpose of the power to regulate them.

Indeed, in 1976, a federal White Paper specifically proposed that "a Canadian Payments Association be established by companion legislation to the Bank Act" and that "[a]1l institutions in Canada accepting deposits transferable by order will be required to join the Association." 214 Effectively, the proposal

209 Report of the Royal Commission on Banking and Finance (Ottawa: Queen's Printer, 1964) at 378

210 Ibid. at 377 .

$211 \mathrm{Ibid}$. at 363 [emphasis added]

212 Ibid. at 378 [emphasis added]

213 The Order in Council setting out its mandate is reproduced in ibid. at 569

214 Canada, Department of Finance, White Paper on the Revision of Canadian Banking Legislation (Ottawa: Supply and Services, 1976). 
was to use the "banking" power to legislate with respect to "institutions accepting deposits transferable by order," namely, institutions accepting deposits out of which funds are transferable by orders. ${ }^{215}$

Accordingly, in its original version, the Canadian Payments Association $A t^{216}$ limited membership to banks, the Bank of Canada, ${ }^{217}$ and any other institution "that accepts deposits transferable by order to a third party." 218 Its uccessor, the Canadian Payments Act, ${ }^{219}$ went further, and did not specify this requirement for new types of members such as life insurance companies and ith regard to them, it is therefore recognized that, even wectiritity relating to their core function in financial intermediation, they are within the reach of the federal "banking" legislative power as long as they provide payment services in their ordinary course of business. 221

Indeed, it is recognized that the debt owed by a paymaster ${ }^{222}$ to a payer need not necessarily be on a "deposit" - no matter how far the latter is broadly taken to mean. Moreover, in performing payment instructions, a paymaster may extend credit to the payer, which is the case for a credit-card issuer. At the same time, the typical relationship between the paymaster and payer is that of a debtor " "While the provision of payment services is not and creditor on a "deposit." While the provision exclusive to banks or even deposit-takers, it is by nature a banking activity ind deposit-taking. At least it has a "rational, functional connection" with the federal head of power ${ }^{223}$ of "banking." As such, it falls within the ambit of federal legislative power in Canada.

215 In fact, even this language is not strictly precise. In a funds transfer, one debt - owed by lank the of bank to same bank to the pay amount. Libjan Arab Foreign Bank v. Bankers Thust Co. (1987), [1989] All E.R. 252 [1988] 1 Lloyd's Rep. 259 at 269 [Lloyd's Rep.], at 273 [All E.R.] (specifically disapproving the dicta in Delbrueck \& Co. v. Manufacturers Hanover Trust Co., 609 F.2d

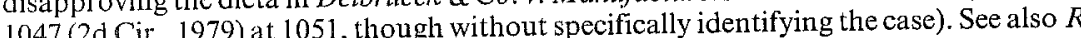
P.eddy (Joln Crawford) [1996] A.C. 815 (U.K. H.L.) at 834. This principle is codified Wreschange) in $B E A$, supra note 31, s. 126

216 Supra note 171

217 Ibid., ss. 4(1)(a)-(c)

218 Ibid., ss. 1 (definitions of "loan company" and "trust company"), 4(2), and 4(4).

219 Supra note 172

220 Ibid. s. 4(d)-(h), under which a life insurance company; a securities dealer; a cooperative credit association; the trustee of a qualified trust; and a qualified corporation, on behal fits money market mutual fund, became eligible for membership.

221 For a similar extension of the federal "banking" legislative power to "banking" activities of non-banks, whether or not they are deposit-takers, see Richard C. Owens \& Nell Guthrie "Foreign Banks' and the 'Business of Banking': Reforming Canada's Foreign Bank Access Regime for the Global Marketplace" (1998) 13 B.F.L.R. 343 at 359-360, Bank Acces 385 .

222 For the paymaster and its role in a payment transaction, see Part 1, supra.

\section{IS THERE SCOPE FOR PROVINCIAL LAW?}

Under section 92 of the Constitution Act,

In each Province the Legislature may exclusively make Laws in relation to Matters coming within the Classes of Subjects next hereinafter enumerated; that is to say,

$\cdots$

11. The Incorporation of Companies with Provincial Objects.

$\cdots$

13. Property and Civil Rights in the Province.

$\ldots$ and

16. Generally all Matters of a merely local or private Nature in the Province.

Subsections 11 and 16 appear to allow provinces to provide laws governing strictly provincial and local payment systems. Thus, subject to being superseded under the federal paramountcy doctrine, discussed further below, and if only on historical grounds, I do not argue against the reading of subsection 11 as allowing provinces to regulate PSPs, and even more in general, non-bank deposit takers, albeit only, in each case, those "with Provincial Objects." Powers under subsections 11 and 16 do not permit a province to provide laws governing payment systems with national scope. Conversely, subsection 13, covering private law, provides a province with a potential inroad into payment laws.

Indeed, in its 2006 GGNPSD report, BIS endorsed the promotion of legal certainty through the development of a transparent, comprehensive, and sound legal framework for the payment system as a guideline for development of a national payment system. ${ }^{224}$ In this context, the GGNPSD report went on to explain that "[t]he legal framework for a national payment system is the body of law which determines the rights and obligations of parties in the system."225 It specifically refers to the "legal framework" as involving both "law of general applicability (such as property, contract, corporate and insolvency laws) that affect the payment system, as well as those that are specific to it (such as payment legislation, netting laws, and clearing house rules)." 226 In principle, other than when they specifically fall under a federal heading, such as in the case of insolvency, "227 "laws of general applicability" relate to "Property and Civil Rights

223 Papp v. Papp, supra note 80.

224 Supra note 6 at 5, 38-42 (Guideline 10) and 63-67 (Annex 4).

225 Ibid. at 38.

226 Ibid. 
in the Province" so as to be assigned to exclusive provincial jurisdiction under section 92(13) of the Constitution Act.

Overlaps between the "Property and Civil Rights" provincial powers and federal specific powcrs are inevitable. On this count, the federal legislative power prevails by invoking one of two legal doctrines. First, interjurisdictional immunity protects core federal competences from encroachment by provincial legislation. The doctrine is rooted in the text of the Constitution Act, 1867, which refers to "exclusivity" throughout sections 91 and $92 .{ }^{228}$ While now of "limited application," the doctrine remains fundamental to the division of powers and, properly applied, "balances the need for intergovernmental flexibility with the need for predictable results in areas of core federal authority." 229 The doctrine applies where the provincial law "trenches on the protected 'core' of a federal competence" and its "effect on the exercise of the protected federal power is sufficiently serious" so as to "impair . . . the federal exercise of the core competence" in a way that "seriously or significantly trammels the federal power." 230

Second, even as overlap of jurisdictions is recognized under the "double aspect doctrine,"231 under what came to be known as "federal paramountcy," "where there are inconsistent (or conflicting) [competent] federal and provincial laws, it is the federal law which prevails." ${ }^{232}$ Federal paramountcy may arise from either the impossibility of dual compliance or the frustration of a federal purpose (or its "intention").

I suppose that, in determining what constitutes "money" in Canada, the intrinsic features of it, and any specific property rules relating to it, interjurisdictional immunity protects the core federal power $^{234}$ in such matters. $^{235}$

227 In Canada, under s. 91(21) of the Constitution Act, supra note 15, the power to legislate in relation to "Bankruptcy and Insolvency" is in Parliament's hands.

${ }^{228}$ Canadian Western Bank v. Alberta, 2007 SCC 22, 2007 CarswellAlta 702, 2007 CarswellAlta 703, [2007] 2 S.C.R. 3, 409 A.R. 207, 75 Alta. L.R. (4th) 1, 49 C.C.L.I. (4th) 1, 281 D.L.R. (4th) 125, [2007] 8 W.W.R. 1, [2007] I.L.R. I-4622, 362 N.R. 111, 402 W.A.C. 207 , [2007] S.C.J. No. 22 (S.C.C.) at para. 34, Laferriere c. Québec (Juge de la Cour du Ouébec) ,2010 SCC 39, 2010 CarswellQue 10212, 2010 CarswellQue 10213, (sub Corr du Quebec), 2010SCC nom. Québec (Procureur général) c. C.O.P.A.) [2010]2 S.C.R. 536, (sub nom. Laferrière v. Québec (Procureur Général)) 324 D.L.R. (4th) 692, 75 M.P.L.R. (4th) 113, (sub nom. Quebec (Attorney General) v. Canadian Owners and Pilots Association) 407 N.R. 102, [2010] S.C.J. No. 39 (S.C.C.) at paras. 25-61 [COPA].

229 COPA, ibid. at para. 58, Canadian Western Bank, ibid. at para. 77.

${ }^{230}$ COPA, ibid. at paras. 27, 43, 45 (McLachlin C.J.'s emphasis).

231 Hodge v. Queen, The (1883), 9 App. Cas. 117 at 130.

232 See Hogg, supra note 28 at 16-2 to 16-3.

${ }^{233}$ COPA, supra note 228 at para. 64.

234 See Part 1 , above.

235 See B. Crawford, "Money in Constitutional Law: The Demise of Debtor-Initiated Payments?" (2015) 56 Can. Bus. L.J. 281.
At the same time, arguably, at least as long as the federal government chooses to be inactive on the point, and notwithstanding the "banking" exclusive federal powers, provinces may pass, as a matter of property and civil rights, laws governing rights of participants in a payment transaction. Looking for legislative models elsewhere, both the German Civil Code ${ }^{236}$ and the Swiss Code of Obligations $^{237}$ treat payment instructions as a matter of "civil rights" other than bills and cheques. More controversially, the Supreme Court of Canada recently upheld provincial legislation addressing a banking transaction governed by specific federal regulations. In the view of the court, the addition by the provincial statute of disclosure requirements and sanctions for their violations was a valid contractual norm as long as it did not contradict the requirements and sanctions provided by federal law. ${ }^{238}$ Under such circumstances, when and as intended, tight and clear drafting of the federal statute has to thrive for exclusivity.

In Part 2(b) above, I argued for exclusive federal jurisdiction with respect to bills and notes, including in wide-sense matters. However, in relation to provincial legislative power, some complexity is introduced due to the strict-and wide-sense dichotomy in what constitutes the law of bills and notes. ${ }^{239}$ As set out below, there are three classes of situations where provincial law could apply to what otherwise would have been "matters coming within bills and notes."

The first class of matters in which provincial law applies is where a federal statute governing bills and notes provides for the determination of certain questions under general law, effectively that of each province. Arguably, this can be done only in relation to wide-sense matters. ${ }^{240}$ For example, $B E A$ section 46 (1) provides that "[c]apacity to incur liability as a party to a bill is coextensive with capacity to contract." Another illustration is $B E A$ section $52(1)$ (a) providing that "[v]aluable consideration for a bill may be constituted by . . . any consideration sufficient to support a simple contract." As directed by the $B E A$, capacity and consideration in relation to bills and notes are thus determined under the general law of contracts in each province. ${ }^{241}$

236 BGB $\$$ \$783-792. Simon L. Goren, The German Civil Code, rev. ed. (Littleton, Colo.: Fred B. Rothman \& Co., 1994).

237 CO Articles 461-471 in Switzerland. For the Swiss Code of Obligations, see supra note 63.

238 Marcotte c. Banque de Montréal, 2014 CSC 55, 2014 SCC 55, 2014 CarswellQue 9001 , 2014 CarswellQue 9002, (sub nom. Bank of Montreal v. Marcotte) [2014] 2 S.C.R. 725, 25 B.L.R. (5th) 173, 374 D.L.R. (4th) 581, 462 N.R. 202 (S.C.C.), critically commented on by Bradley Crawford, "Marcotte c. Banque de Montréal: 'Exclusive' Federal Financial Consumer Protection Law and the Role of the Law of Contract" (2015), 30 B.F.L.R. 345.

239 .For both points with regard to exclusive federal jurisdiction and the wide- versus strictsense dichotomy in relation to "matters coming within bills and notes," see Part 2(a).

240 This is so since, by definition, provinces are precluded from addressing "strict sense" matters.

241 As for consideration, see Crawford, Banking and Payment, vol. 3, supra note 69, s. 27:30. Note that the reference to the general law of the province (s. $52(1)(a))$ is accompanied by a 
Second, the $B E A$ has been construed to mean that subjects not provided for by express provisions of a federal statute, insofar as they are not part of the law of bills and notes in the strict sense, are governed by general provincial laws. ${ }^{242}$ This is nolwithstanding the languagc of scction 9 of the Act, providing that " $[t]$ he rules of the common law of England, including the law merchant, save in so far as they are inconsistent with the express provisions of this Act, apply to bills, notes and cheques." It was held that "Section 9 of the $B E A$ applies only to the rules relating to bills [and notes] not covered by the $B E A$, not to the general [supplementary] law." 243 This juxtaposition must be taken to mean that, as opposed to supplementary law, "rules relating to bills, notes and cheques," of which $B E A$ section 9 speaks, are only those relating to strict-sense matters. It was accordingly decided that whether an endorser is discharged by the giving of time by the holder to the maker after the maturity of the note is not a strict-sense matter. Consequently, the point ought not to be explored through $B E A$ section 9 . Rather, being a wide-sense matter, it is to be determined according to the general law of the province governing rights of a surety. ${ }^{244}$

It is noteworthy that $B E A$ section 9 speaks of "rules of ... the law merchant" as included in "[t]he rules of . . the common law." The former are said to be "usagess of merchants and traders," including those already "ratified by the decisions of Courts of law." 245 However, on the basis of recent research carried out by Rogers ${ }^{246}$ and pursued by me, ${ }^{247}$ it may be pointed out that "the law merchant" and "custom" were effective tools in the development of the common law itself as it had been positioned to cover the bill of exchange. With the evergrowing expansion of commerce, more than true sources for normative rules, "law merchant" and "custom". were vocabulary, codes for a set of terms, or a frame of reference, which allowed Common Law Courts to expand the frontiers of liability with the view of satisfying the requirements and expectation of the mercantile community. The alleged "reception" 248 "was in reality nothing other

specific common law rule: an antecedent debt or liability is consideration for a bill or note (s. 52(1)(b))

242 Crawford, Banking and Payment, ibid., s. 21:40.80(3),

243 Banque Toronto Dominion c. Caisse populaire Desjardins de Côte-des-Neiges, 2011 QCCA 1148, 2011 CarswellQue 5814, 2011 CarswellQue 11977, EYB 2011-191973 (C.A. Que.) at note 1, per Dalphond J.A., who added that "this is all the more true since the addition of sections 8.1 and 8.2 of the Interpretation Act, RSC 1985, C. I-21, proclaiming the duality of legal traditions." However, in my view, the leap from common - civil law duality to federal - provincial duality is not well founded even in a case where the particular federal law draws on the common law and the provincialone draws on the civil law.

244 Guy v. Paré, 1892 CarswellQue 324, 1 Que. S.C. 443 (Que. Ct. of Review).

245 Goodwin v. Robarts (1875), supra note 94.

246 James Steven Rogers, The Legal History of the Law of Bills and Notes (Cambridge, U.K.: Cambridge University Press, 1995) at 125-150.

247 Geva, The Payment Order, supra note 3 at 442-453. than a refinement of the common law which had always governed mercantile affairs." 249

What then are "rules of . . the common law" other than "rules of . . the law merchant," which relate to strict-sense matters so as to be covered by BEA section 9? Possibly they refer to rules that developed in the common law specifically for bills and notes - albeit not during the post-Medieval formative era. A tentative cut-off point may be the passage of the $B E A$ in England. An example of such a common law rule that prevails over any inconsistent or conflicting provincial law may be the finality of payment with respect to payment made by a drawee bank in ignorance of a forged drawer's signature. Under certain circumstances, such a bank may be denied a restitutionary remedy against the bona fide recipient of the payment. ${ }^{250}$ Another example may be the scope of the defence of non est factum (NEF) against a holder in due course. ${ }^{251}$

The third occasion for provincial law to apply is under the "double aspect doctrine." 252 Under this doctrine, "subjects which in one aspect and for one purpose fall within sect. 92 [of the Constitution Act], may in another aspect and for another purpose fall within sect. $91 . " 253$ In a context not involving bills and notes it was held that "the federal jurisdiction over interest [under the Constitution Act section 91(19)] does not exclude all provincial jurisdiction [in relation to property and civil rights under Constitution Act section 92(13)] over contracts involving the payment of interest." Consequently, such federal jurisdiction does not invalidate "provincial laws authorizing the Courts to grant relief from such contracts, when they are adjudged to be harsh and

248 For this alleged reception as the orthodox position, see Holdsworth, supra note 38 at 151.

249 John H. Baker, "The Law Merchant and the Common Law Before 1700" (1979) 38 Cambridge L.J. 295 at 322.

250 The rule of Price v. Neal (1762), 3 Burr. 1355, as was explained in National Westminster Bank Ltd. v. Barclays Bank International Ltd. (1974), [1975] 2 W.L.R. 12 (Que. B.D.) and in Barclays Bank Ltd v. WJ Simms Son \& Cooke (Southern) Ltd. (1979), [1980]2 W.L.R. 218 (Que. B.D.) at 237. However, this explanation can be seen as given as a matter of $B E A$ statutory interpretation rather than a common law rule. In any event, this explanation was overlooked in Canada, where the usual common law rule was held to protect an innocent payee paid on a forged cheque who changed his position. See B.M.P. Global Distribution Inc. v. Bank of Nova Scotia, 2009 SCC 15, 2009 CarswellBC 809, 2009 CarswellBC 810, [2009]1 S.C.R. 504,94 B.C.L.R. (4th) 1, 58 B.L.R. (4th) 1, 304 D.L.R. (4th) 292 , [2009] 8 W.W.R. 428,268 B.C.A.C. 1, 386 N.R. 296, 452 W.A.C. 1, [2009] A.C.S. No. 15, [2009] S.C.J. No. 15 (S.C.C.).

251 Such a special tule was stated to exist in Carlisle \& Cumberland Banking Co. v. Bragg (1910), [1911] 1 K.B. 489 (Eng. C.A.). But see Lord Denning's criticism in Gallie v. Lee, [1969] 2 W.L.R. 901 at 910 (C.A.). The House of Lords (1970), [1971] A.C. 1004 (U.K. H.L.) (sub nom. Saunder's v. Anglia Bldg. Soc.) affirmed Lord Denning's decision and overruled Carlisle and Cumberland Banking Co. v. Bragg. It was nonetheless acknowledged by Lord Wilberforce that "special rules may apply" to negotiable instruments: (1970), [1971] A.C. 1004 (U.K. H.L.) at 1027.

${ }^{252}$ See Hogg, supra note 28, s. 15.5(c).

${ }^{253}$ Hodge v. Queen, The (1883), 9 App. Cas. 117 at 130. 
unconscionable."254 Accordingly, provincial jurisdiction over property and civil rights extends to contracts involving bills and notes.

Nonetheless, having passed the test of validity, a provincial law could still be defeated under the doctrine of "federal paramountcy." Thereunder, "where ther are inconsistent (or conflicting) federal and provincial laws, it is the federal law which prevails." 255 Thus, insofar as "matters coming within bills and notes" are concerned, the express provisions of the federal $B E A$ supersede any conflicting or inconsistent, even if valid, provincial laws. For example, a province could provide rules with respect to warranties on the transfer of property, could establish as a general rule that no transferee could ever acquire more rights than his or her transferor had, or could provide that the use of bills and notes in certain situations is unconscionable. Such laws are valid and applicable to bills and notes. They are, however, to be superseded in relation to bills and notes by and notes. They are, however, to be superseded in relation to bills and notes by the exprest sense or, assuming federal jurisdiction as explained in Part 2(b) above, also in the wide sense. They are also to be superseded by uncodified "strict sense" rules relating to bills and notes. To pursue the previous examples, section 137 of the $B E A$ dealing with warranty by transferor (a matter that is part of the law of bills and notes in the wide sense) would supersede the hypothetical provincial statute governing warranties on the transfer of property. This is true even if the latter purports to cover bills and notes specifically. By the same token, the provisions of the $B E A$ applicable to the right of a holder in due course (which are part of the law of bills and notes in the strict sense) prevail over the hypothetical provisions with respect to the transferee's disabilities. As well, a provincial statute could regulate the use of bills and notes; it cannot prevent a bona fide purchaser for value of bills and notes issued (or not marked) in violation of a provincial statute from becoming their holder in due course. ${ }^{256}$

Federal paramountcy applies wherever federal and provincial laws, each valid, are "incompatible." The doctrine was held to exist even where "the provincial legislature acts within its primary powers, and Parliament pursuant to ancillary powers, ${ }^{257}$ assuming, as discussed in Part 2(b) above, such powers exist. Furthermore, the effect of the doctrine of federal paramountcy is not only

254 Toinell Investments Ltd. v. East Markstock Lands Ltd. (1977), 1977 CarswellOnt 468, 1977 CarswellOnt 422, [1978] 1 S.C.R. 974, 77 D.L.R. (3d) 145, 2 R.P.R. 69, 16 N.R. 139 1977 CarswellOnt 422, [1978] 1 S.C.R. 974, 77 D.L.R. (3d) 145, 2 R.P.R. 69,16 N.R. 139 (S.C.C.) at 152-153 [D.L.R.], explaining the majority's view in On. (2d) 137 (S.C.C.)

255 Hogg, supra note 28 at ch. 16.

256 Duplain v. Cameron, 1961 CarswellSask 55, [1961] S.C.R. 693, 30 D.L.R. (2d) 348, 36 W.W R 490 (S.C.C.) Quaere whether provincial law is nonetheless relevant in defining "honesty" for the purpose of denying "good faith" (s. 3 of the BEA).

257 Canadian Western Bank v. Alberta, 2007 SCC 22, 2007 CarswellAlta 702, 2007 CarswellAlta 703 [2007]2 S.C.R. 3, 409 A.R. 207,75 Alta. L.R. (4th) 1, 49 C.C.L.I. (4th) 1.281 D.L.R (4th) 125, [2007] 8 W.W.R. 1, [2007] I.L.R. I-4622, 362 N.R. 111, 402 W.A.C. 207, [2007] S.C.J No. 22 (S.C.C.) at para. $69[\mathrm{CWB}]$ to assign precedence to federal statutes but also to entrench common law rules that are part of the law of bills and notes in the strict sense. Such common law rules prevail over valid provincial laws, even where the latter laws are embodied in a provincial statute that purports to supersede the former rules. This aspect of federal paramountcy is the result of the effectiveness given to the common law rules relating to strict-sense aspects under $B E A$ section 9 as discussed above. Thus, as applied to bills and notes, a "strict sense" common law principle will prevail over a valid provincial "wide sense" law - even statutory. ${ }^{258}$

The preceding analysis is consistent with the leading authority on the application of the doctrine of federal paramountcy in relation to bills and notes. Thus, in Atlas Lumber Co. v. Winstanley $(1940)^{259}$ the Supreme Court of Canada reviewed a provincial statute providing that no action for the recovery of a liquidated sum of money could be taken without the permit of a provincial administrative body. ${ }^{260}$ The court held that the statute could not supersede ${ }^{261}$ the holder's right of action on a promissory note. Five members of the court relied on (what is now) section 73 of the $B E A$ either alone or together with (what are now) sections 133,134 , and $135 .^{262}$ They read the Act as conferring a right of action on the holder of a bill or note and to override conflicting provincial legislation. Davis $J$. declined to read (what is now) section 73 (setting out rights and powers of a holder) as providing for the holder's right of action and based his decision on another ground. ${ }^{263}$ He correctly pointed out that the rule under which "the holder of a bill" "may sue on the bill in his own name" per what is now $B E A$ section 73(a) only means that he is not liable to be defeated in an action on the bill on the ground that the action has been brought by the wrong party. Even if so, he overlooked the fact that the holder's independent right of

258 But see Ziegel \& Denomme, supra note 104 at 20 , stating that "the overriding federal jurisdiction [in relation to bills and notes] does not preclude the provinces from regulating aspects of negotiable instruments law under their property and civil rights power so long as the provincial legislation does not conflict with the federal legislation"
[emphasis added]. This proposition overlooks the overriding effect of the uncodified "strict sense" rule.

259 (1940), 1940 CarswellAlta 59, [1941] S.C.R. 87, [1941] 1 D.L.R. 625 (S.C.C.).

${ }^{260}$ Specifically, the Debt Adjustment Act, 1937, S.A. 1937, c. 9, s. 8 stated that "no action or suit for the recovery of any money which is recoverable as a liquidated demand or debt in respect to any claim enforceable by virtue of any rule of law or equity or by virtue of any statute... shall be taken... by any person whom spever against a resident debtor in any case" unless the board constituted by the Act and appointed by the provincial government issues a permit consenting thereto.

261 Characterizing the provincial statute as "ultra vires," as repeatedly said in the judgment, is nonetheless inaccurate.

262 These provisions (relied on in full or in part by Duff C.J., Kerwin, Rinfret, Hudson, and Taschereau JJ.) address the rights and powers of a holder as well as damages recovered by him upon dishonour.

${ }^{263}$ He held that a provincial legislature cannot confer what is in fact a judicial authority upon its own nominee to decide whether a suitor shall have access to the provincia courts, at least in relation to a matter within the exclusive power of Parliament. 
action is a rule of the law of bills and notes in the strict sense. ${ }^{264}$ In the final analysis, far beyond merely providing for a defence to an action on a bill or note, the provincial statute subjected an unconditional right to "sue" prescribed by federal law to conditions and administrative discretion.

This analysis explains the result of Duplain v. Cameron (1962). ${ }^{265}$ The case dealt with a provincial statute regulating the trade in securities. The statute required the registration of securities traders. "Securities" were defined to include certain promissory notes. The majority of the Supreme Court of Canada rejected a constitutional challenge to the application of the statute to promissory notes. Kerwin C.J.C. stressed the valid provincial purpose of the statute as well as the fact that "there is nothing [in the provincial statute] to prevent the holder of a promissory note . . from suing upon the document." 266 Ritchie J. upheld the constitutionality of the provincial statute inter alia because "none of [its provisions] ... has any effect on the form, content, validity or enforceability of promissory notes or is otherwise concerned with the "law of bills and notes in the strict sense." 267 Nor was there any conflict with an express provision of the $B E A$. At the same time, Locke J., who dissented, regarded the provincial statute as inconsistent with the free negotiability of promissory notes. Apparently he viewed the right "to negotiate ... promissory notes freely in the conduct of ... business" 268 as a principle of law that as part of the law of bills and notes in the strict sense prevails over the restrictions of the inconsistent provincial statute even when it is not codified.

In McGillis v. Sullivan $(1947),{ }^{269}$ the Ontario Court of Appeal discussed a provision of a provincial Gaming $A c t^{270}$ dealing with illegal consideration for a bill or note. The provision conferred on the loser of a wager a right to recover money, or some other valuable thing, paid or delivered to the winner. Recognizing that " $[t]$ he worth and adequacy of money, or other valuable thing, as consideration for a note or bill falls within the provisions of the

264 In the 1878 edition of his book on the law of bills of exchange, Chaimers (who does not distinguish between the law merchant and common law rules relating to bills and notes) defined "holder" as "the person in possession of a bill, who by the Law Merchant is entitled to enforce the payment thereof" (Mackenzie D. Chalmers, A Digest of the Law of Bills of Exchange, Promissory Notes and Cheques, (London: Stevens and Sons, 1878) at 3) Cf David A L Smout ed Chalmers on Bills of Exchange, 13th ed. (London: Stevens \& Sons, 1964) at 8 , referring to the holder as "the mercantile owner of the instrument."

265 Supra note 256.

$260 \mathrm{Ibid}$. at 354. Taschereau, Fauteux, and Judson JJ, concurred. See also the decision of Cartwright $\mathbf{J}$.

267 Ibid. at 366

268 Ibid. at 357

2691947 CarswellOnt 70, [1947] O.R. 650, 89 C.C.C. 286, [1947] 4 D.L.R. 113 (Ont. C.A.); affirmed on other grounds 1949 CarswellOnt 112, [1949] S.C.R. 201, 93 C.C.C. 175, [1949] 2 D.L.R. 305 (S.C.C.).

270 R.S.O. 1937 , c. 297. [contested] section," Laidlaw J.A. nevertheless thought that "the section is not in substance legislation as to bills of exchange and promissory notes" and upheld its validity. ${ }^{271}$

In the course of his judgment, Laidlaw J.A. pointed out that the provincial legislation neither prevented nor prohibited the use of bills or notes given for gambling debts and did not destroy their value in the hands of persons other than the winner of money or other valuable thing described in the enactment. He went on to explain that the section under attack dealt only with the rights and relationship between the loser and the winner in a gaming transaction and did not extend to third persons. While affecting bills and notes, insofar as it did not infringe upon the federal legislation dealing with holders in due course, the section was not in substance legislation as to bills of exchange and promissory notes. Rather, the "pith and substance" of the legislation was a matter of property and civil rights within the competency of the province.

Relying on McGillis, the Manitoba Court of Appeal upheld in Red River Forest Products Inc. v. Ferguson ${ }^{272}$ the constitutionality of provisions of a Gambling $A c t^{273}$ applicable in the province. ${ }^{274}$ The provincial statutory provision deemed a promissory note issued for a gambling debt to be given for illegal consideration. An endorsee not meeting the holding in due course requirements ${ }^{275}$ was thus prevented from enforcing the note against the loser who signed it. ${ }^{276}$

Had pertaining provincial legislation in both McGillis and Red River Forest characterized gambling debt as illegal consideration generally, there would have been no doubt as to its constitutional validity. Such legislation would have affected indirectly liability on a bill or note given for the debt. This is so since, in principle, other than as against a holder in due course, defences available under provincial law in an action on a debt may also be raised in an action on the bill or note given for the debt. ${ }^{277}$ However, in both cases the provincial legislation purported to deal directly with a gambling debt as illegal consideration for a "bill" or "note."

Nevertheless, the result in both cases, upholding provincial legislation directly applicable to bills and notes, may be explained on three grounds. First, the specific provincial reference to bills and notes must have been made in the

271 McGillis, supra note 262 at para. 32.

272 (1992), 1992 CarswellMan 149, 8 C.P.C. (3d) 328n, 98 D L.R. (4th) 697, [1993] 2 W.W.R. 1, 83 Man. R. (2d) 27, 36 W.A.C. 27, [1992] M.J. No. 556 (Man. C.A.)

273 Gambling Act (U.K.), 5 \& 6 Will. IV, c. 41 (U.K.).

274 Court of Queen's Bench Act, S.M. 1874 c. 12 (38 Vic., c. 12).

275 Set out in $B E A$, supra note 31 , s. 55.

276 Among other sources, the judgment cites my earlier article on the subject, Benjamin Geva, "Preservation of Consumer Defences: Statutes and Jurisdiction" (1982) 32 U.T.L.J. 176

277 As indicated in Part 2(a), above, freedom from adverse claims to an instrument as well as from prior party's defences is reserved to a holder in due course (BEA, s. 73(b)). 
context of rendering gambling debts illegal generally. Second, as discussed, what is "[v]aluable consideration for a bill [which under $B E A$ section $52(1)(a)$ ] may be constituted by ... any consideration sufficient to support a simple contract" is determined under provincial law. Although illegality of consideration is not determined under provincial law. Although illegality of consideration is not valid "valuable consideration" - as determined by provincial law - and required to support liability on a bill or note. Third, one could perhaps go further and conclude that even provincial legislation that relates specifically and exclusively to bills and notes is good law, as long as it addresses "wide sense" matters as applied to bills and notes - and is not inconsistent with both a federal statute relating to bills and notes and an uncodified "strict sense" principle.

Arguably, the third ground is the most appealing. Accordingly, for provincial legislation to be valid, two conditions must be met. First, the provincial statute should not affect a "strict sense" matter. Second, the statute ought not to be contrary to a specific valid federal provision, even where the latter addresses a "wide sense" subject. As a matter of "property and civil rights," provincial legislation meeting these two conditions is thus valid, even if it specifically addresses property and contract law aspects of bills and notes. A good example is section $19(2)(2)$ of the Ontario Execution $A c t^{278}$ dealing with the seizure of a negotiable instrument on behalf of an execution creditor.

Nevertheless, a few hard cases are not easily reconcilable. Thus, limitation of time for actions on promissory notes was held to be within provincial legislative authority. ${ }^{279}$ Similarly, provincial "seize or sue" legislation precluding a secured party who repossessed the collateral from recovering on a debt instrument party who repossessed the collateral from recovering on a debt instrument in general, both the limitation of actions and creditors' rights fall under provincial jurisdiction as "property and civil rights" matters. At the same time, as in Atlas Lumber, ${ }^{281}$ in relation to bills and notes, such legislation results in curtailing the holder's right to sue. As such, it seems unavoidable to conclude that it "trespasses" into a strict-sense matter. Distinction based, for example, on an alleged procedural nature of a statute of limitations is not persuasive an alleged

278 Execution Act, R.S.O. 1990, c. E-24.

279 See e.g. Weingarden v. Moss, 1955 CarswellMan 30, [1955] 4 D.L.R. 63, 15 W.W.R. 481 3 Man R. 243 at 253 (Man. C.A.) at para 31, per Coyne J.A., citing with approval Maclaren on Bills, Notes and Cheques, 6th ed., at 17.

280 For a comprehensive discussion, see e.g. J. Watson Hamilton, "When Is a Pronissory Note a Covenant to Pay under a Mortgage on Land?" (1996-97) 12 B.F.L.R. 221 at 233-

281 Supra note 259.

282 For the modern view under which the operation of a statute of limitation is a question of substantive law not only under the civil law but also in the common law, see the judgment of LaForest J. in Tolofson v. Jensen (1994), 1994 CarswellBC 1, 1994 CarswellBC 2578,
Crawford is of the view that, in principle, a provincial statute may not fasten a limitation period on a holder of a bill or note. ${ }^{283}$ Nor can a provincial statute deny from the holder the right to sue the debtor for the deficiency after repossession. ${ }^{284}$ Accordingly, in his view, cases to the contrary were wrongly decided. It is hard to argue against the logic of this position. Certainly I do not question the existence of a federal legislative power in matters of (i) limitation period for an action on a bill or note as well as (ii) enforcement of collateral given to secure an obligation on a bill or note. However, it is unlikely that Parliament, in refraining from providing, e.g., for a limitation period for bills and notes, meant to exempt the holder from the application of general legislation on limitations of action. At the same time, to suggest that provincial legislation covering limitation of time for an action on a bill or note is binding as long as Parliament has not dealt with the subject ${ }^{285}$ is to bring in the "double aspect" doctrine, which per Atlas Lumber has no room for in a strict-sense matter.

Undoubtedly, it is within the power of a province to legislate as to debts paid by means of a bill or note. As a matter of property and civil rights a province may thus restrict the enforcement of an action on a debt or extinguish the debt altogether. The issue as to the effect of such a restriction or extinguishment on the bill or note with which this debt is paid becomes then a question to be determined by the law of bills and notes in the strict sense. ${ }^{286}$ While there is no ready-made answer to the question, the chance is that a defence based on a restriction on the action on or extinction of the underlying debt will be effective against the holder's action on the bill or note with which the debt has been paid, albeit probably not where he is a holder in due course. ${ }^{287}$

Furthermore, arguably, even cases upholding the application of statues of limitations as well as "seize or sue" provisions directly to bills and notes (and not only to the debt paid by them) may be "saved." This can be done by pointing out that the holder's right to sue, being a codified principle of the law of bills and notes in the strict sense, is nonetheless not meant, even under the law of bills and notes in the strict sense, to be absolute. Accordingly, provincial law barring the holder's action on grounds that are contrary to neither federal statute nor a principle under the law of bills and notes in a strict sense is valid. Thus, there is

1022, 100 B.C.L.R. (2d) 1, 26 C.C.L.I. (2d) 1, 22 C.C.L.T. (2d) 173, 32 C.P.C. (3d) 141 120 D.L.R. (4th) 289, 7 M.V.R. (3d) 202, [1995] 1 W.W.R. 609, 51 B.C.A.C. 241,175 N.R. 161, 77 O.A.C. 81,84 W.A.C. 241 , [1994] S.C.J. No. 110 (S.C.C.) at 319 [D.L.R.]

${ }^{283}$ Crawford, Banking and Payment, vol. 3, supra note 69, s. 28:110.30.

284 Ibid., s. 20:30.20(3)(b)

285 As was suggested in Wiengarden, supra note 279.

286 A debt paid by a bill or note is presumed to be suspended until discharge or dishonour. Charge Card Services Ltd (No.2), Re, [1988] 3 All E.R. 702 (Eng. C.A.). This, however, does not tell as to the effect of a statutory restriction on, or extinction of, the debt.

287 A holder in due course may not be immune from defences that are based on the nullity of the debt paid by means of the instrument on which he is suing. See e.g. Gallie v. Lee, [1969] 2 Ch. 17 (Eng. C.A.); affirmed (1970), [1971] A.C. 1004 (U.K. H.L.) 
nothing in the $B E A$ nor otherwise in the law of bills and notes in the strict sense to say that the holder's enforcement right exists notwithstanding a limitation period or the seizure of the collateral that secures the obligation on the bill or note. Conversely, the grounds of forfeiting the holder's right according to the Alberta statute dealt with in Atlas Lumber ${ }^{288}$ were objectionable as a matter of the law of bills and notes in the strict sense. Hence, (what is now) $B E A$ section 73(a) ought to be read as superseding it. For certain, this reasoning narrows down the scope of Atlas Lumber, and yet facilitates greater harmony between provincial and federal laws.

\section{CONCLUSION}

Arguably, albeit as a matter of progressive interpretation, the bills and notes federal legislative power under section 91(18) of the Constitution Act may be stretched to encompass all payment instructions and not only those given on bills or cheques. In any event, the operation of the non-cash payment system is premised on, even if not limited to, inter-deposit bank transfers. Hence, it is argued in this article, the federal legislative power over the entire payments area draws primarily on the "banking" power of section 91(15) of the Constitution Act.

Provinces may use their powers under the Constitution Act sections 92(11), (13), and (15) in relation to the incorporation of companies with provincial objects, property and civil rights, and matters of a merely local or private nature. However, once such matters become part of a national payment system, inconsistent provincial laws will be superseded by competent federal legislation.

Efficiency and legal certainty will be promoted by a uniform legal framework. This does not mean that money transmitters ought to be regulated as heavily as banks ${ }^{289}$ or that retail payment systems are to be subject to the same treatment as wholesale/large-value systems. ${ }^{290}$ Rather, regulation of each such category in Canada ought to be uniform. For sure, a strong case can be made for federal regulation of all national institutions and activities. Indeed, as for rights federal regulation of all national institutions and action provincial statute, passed under the property and civil rights power, may not be ruled out as an option. under the property and civil taking into account existing federal exclusive powers on matters such as currency, bills and notes, and banking, and hence the federal government's as currency, bills and notes, and regulation of the national financial system, the federal avenue for comprehensive regulation and legislation of payment methods and systems is the most promising.

288 Supra note 259.

249 For a possible regulatory approach, see e.g. Preamble (11) to Directive 2007/64/EC of the European Parliament and of the Council of 13 November 2007 on payment services in the internal market O.J., L 319/1, 5.12.2007.

290 A point acknowledged in Balancing Oversight and Innovation in the Ways We Pay, supra note 178. 